Winter 2010

\title{
Immigration as Invasion: Sovereignty, Security, and the Origins of the Federal Immigration Power
}

Matthew Lindsay

University of Baltimore School of Law, mlindsay1@ubalt.edu

Follow this and additional works at: http://scholarworks.law.ubalt.edu/all_fac

Part of the Immigration Law Commons, International Law Commons, and the Supreme Court of the United States Commons

\section{Recommended Citation}

Immigration as Invasion: Sovereignty, Security, and the Origins of the Federal Immigration Power, 45 Harv. C.R.-C.L. L. Rev. 1 (2010)

This Article is brought to you for free and open access by the Faculty Scholarship at ScholarWorks@University of Baltimore School of Law. It has been accepted for inclusion in All Faculty Scholarship by an authorized administrator of ScholarWorks@University of Baltimore School of Law. For more information, please contact snolan@ubalt.edu. 


\title{
Immigration as Invasion: Sovereignty, Security, and the Origins of the Federal Immigration Power
}

\author{
Matthew J. Lindsay*
}

\begin{abstract}
This Article offers a new interpretation of the modern federal immigration power. At the end of the nineteenth century, the Supreme Court and Congress fundamentally transformed the federal government's authority to regulate immigration, from a species of commercial regulation firmly grounded in Congress's commerce authority, into a power that was unmoored from the Constitution, derived from the nation's "inherent sovereignty," and subject to extraordinary judicial deference. This framework, which is commonly referred to as the "plenary power doctrine," has stood for more than a century as an anomaly within American public law. The principal legal and rhetorical rationale for the plenary power doctrine was and remains the supposition that the regulation of immigration is always inherently related to the conduct of foreign affairs, and, especially, to national security.

By situating this radical yet extremely durable doctrinal transformation within its appropriate intellectual and political context, this Article seeks to denaturalize the "national security rationale" for immigration exceptionalism. It argues that the plenary power doctrine was borne of an urgent sense of national peril, the basic terms of which most contemporary policymakers, judges, and scholars would emphatically reject. Although the doctrine made its judicial debut in the Chinese Exclusion Case, its historical origins in fact lie largely beyond Chinese exclusion in a much broader contemporaneous critique of (mostly European) immigration. The late nineteenth-century architects of the plenary power doctrine believed that the unchecked immigration of economically degraded, politically inassimilable, and racially unfit immigrants had created a state of national emergency. In response, the Court fashioned an immigration power adapted not to the regulation of labor, or economic dependency, or crime-issues that, then as now, characterize most immigration lawmakingbut rather to the defense of the nation against foreign aggression.

Although the immigrants upon whom this power was exercised were citizens of ostensibly "friendly" nations, policymakers and judges re-imagined them as enemy aliens. Through this process, the Court in effect invented the "immigrant" as a distinct, and distinctly consequential, legal construct.
\end{abstract}

* Assistant Professor, University of Baltimore School of Law. M.A. History, University of Chicago, 1995; J.D. Yale Law School, 2002; Ph.D. History, University of Chicago (expected 2010). For their valuable insights, I am grateful to Bethany Berger, John Coyle, Owen Fiss, David Fontana, Willy Forbath, Christian Ford, Tara Grove, Sam Issacharoff, Michael Klarman, Nora Lindsay-Reilly, Martha Minow, Gerry Neuman, Kim Reilly, Don Sharfstein, Jed Shugerman, Mark Tushnet, and Stephen Williams. 
Contents

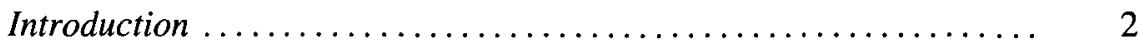

I. Before Immigration Exceptionalism: Sovereignty and Commerce in the Nineteenth Century ............... 9

A. "Free Immigration" in the Young Republic ......... 10

B. Police vs. Commerce ...................... 13

1. City of New York v. Miln ............... 14

2. The Passenger Cases .................. 17

C. The Federalization of the Immigration Power....... 23

1. The Demise of State Sovereignty............ 24

2. The "Business of Immigration": Foreign Commerce and the Consolidation of the Federal Immigration Power........................... 27

II. "National Security" and the Birth of the Plenary Power Doctrine .................................. 31

A. Immigration as Foreign Aggression ............. 33

B. "The National Right of Self-Preservation"......... 40

1. The Chinese Exclusion Case.............. 40

2. The Triumph of Plenary Power: Legislative and Judicial Consolidation .................... 46

III. Conclusion: Toward an Unexceptional Immigration Power. 52

\section{INTRODUCTION}

It is a "fundamental premise of immigration law," the Supreme Court recently reaffirmed, that "[i]n the exercise of its broad power over naturalization and immigration, Congress regularly makes rules that would be unacceptable if applied to citizens." Such constitutional latitude is warranted, the Court explained, because "any policy toward aliens is vitally and intricately interwoven with contemporaneous policies in regard to the conduct of foreign relations, the war power, and the maintenance of a republican form of government." 2 With this rationale, the Court upheld the mandatory detention of Hyung Joon Kim, a long-term permanent resident who had lived in the United States since age six, during the six-month pendency of his removal proceedings. ${ }^{3}$ Kim had become subject to removal after he was twice caught shoplifting and later convicted of burglary for breaking into a tool shed with some high school friends-all within a ten-month period when he

\footnotetext{
${ }^{1}$ Demore v. Hyung Joon Kim, 538 U.S. 510,521 (2003) (quoting Mathews v. Diaz, 426 U.S. $67,79-80(1976)$ ).

${ }^{2}$ Id. at 522 (quoting Mathews, 426 U.S. at 81 n.17).

${ }^{3}$ The Court upheld Section 1226(c) of the Immigration and Nationality Act ("INA"), "requiring the Attorney General to detain a subset of deportable criminal aliens pending a determination of their removability." Id. at 521 .
} 
was eighteen and nineteen years old. ${ }^{4} \mathrm{He}$ had been detained without bail, notwithstanding the government's determination that he posed neither a flight risk nor a threat to the community. ${ }^{5}$ Exactly how Kim's detention bore on foreign relations, or war, or republican government, the Court never explained.

The consignment of routine immigration matters such as Kim's-involving, for example, removal for criminal convictions or visa noncompliance-to the constitutional netherworld typically reserved for the conduct of war and foreign affairs is both constitutionally and morally striking. Yet this principle, which is commonly referred to as the "plenary power doctrine,"6 is one of the most enduring constructs in American public law. Indeed, such extraordinary judicial deference has been a cardinal feature of the federal immigration power since the Supreme Court first adopted the plenary power doctrine in the 1889 Chinese Exclusion Case. ${ }^{7}$ Two basic elements define the doctrine. First, Congress's authority to regulate immigration derives not from any constitutionally enumerated power, but rather is "inherent" in the United States" "sovereignty" as an independent nation. Second, in its exercise of that authority, Congress - and, by delegation, the Executive-is buffered against judicially enforceable constitutional constraints. ${ }^{8}$ The consequences for Hyung Joon Kim and millions of other immigrants can be profound and far-reaching. For non-citizens denied entry at the border, "[w]hatever the procedure authorized by Congress is, it is due process ...." Even long-term legal residents lack robust constitutional protections against, for example, improper detention during often lengthy removal proceedings; $; 0$ selection for removal because of otherwise constitutionally pro-

\footnotetext{
${ }^{4}$ For an informative overview of the Kim case, see Margaret H. Taylor, Demore v. Kim: Judicial Deference to Congressional Folly, in IMMIGRATION STORIEs 343-76 (David A. Martin \& Peter H. Schuck eds., 2005).

s See Kim, 538 U.S. at 515. The Immigration and Naturalization Service ("INS") had declared sua sponte during the district court proceeding "that Kim "would not be considered a threat' and that any risk of flight could be met by a bond of $\$ 5,000$." Id. at 541 (Souter, J., concurring in part and dissenting in part).

6 The use of the term "plenary power" to denote a power that is, as I will explain below, both unenumerated and buffered against constitutional review, is somewhat misleading. As Justice John Marshall made clear nearly two centuries ago, historically, "plenary" has referred to powers that are both enumerated in and constrained by the Constitution. He wrote: "If, as has always been understood, the sovereignty of Congress, though limited to specified objects, is plenary as to those objects, the power over commerce with foreign nations, and among the several States, is vested in Congress as absolutely as it would be in a single government, having in its constitution the same restrictions on the exercise of the power as are found in the [C]onstitution of the United States." Gibbons v. Ogden, 22 U.S. 1, 197 (1824). (1889).

${ }^{7}$ Chae Chan Ping v. United States (The Chinese Exclusion Case), 130 U.S. 581, 609

${ }^{8}$ For the classic formulation of the plenary power doctrine, see id. at 609 ; see also Fong Yue Ting v. United States, 149 U.S. 698, 705 (1893); Nishimura Ekiu v. United States, 142 U.S. 651,659 (1891).

${ }^{9}$ Knauff v. Shaughnessy, 338 U.S. 537, 544 (1950).

${ }^{10}$ See Demore v. Hyung Joon Kim, 538 U.S. 510, 540-41 (2003) (Souter, J., concurring in part and dissenting in part).
} 
tected speech or associations;" ${ }^{11}$ or discrimination on the basis of alienage with respect to eligibility for public benefits. ${ }^{12}$ As this partial list of constitutional disabilities suggests, ${ }^{13}$ the plenary power doctrine survived largely unscathed by Congress's broad liberalization of substantive immigration policy in $1965^{14}$ and the revolution in civil rights and due process of the $1960 \mathrm{~s}$ and 1970s. Accordingly, scholars and courts alike have long noted, and often decried, the constitutional exceptionalism of the immigration power within American public law. ${ }^{15}$

This Article reconstructs the history of the federal immigration power, with two specific goals. First, it refines our understanding of the power's origins and development by explaining how the Supreme Court and Congress transformed it from a species of commercial regulation grounded in Congress's constitutionally enumerated commerce authority and subject to judicially enforceable constraints, into a power inherent in national sovereignty and buffered against constitutional review. Second, the Article seeks to denaturalize the basic legal and rhetorical rationale for immigration ex-

11 See Reno v. Arab-American Anti-Discrimination Comm'n, 525 U.S. 471 (1999).

12 See Mathews v. Diaz, 426 U.S. 67, 80-84 (1976).

${ }^{13}$ Constitutional deference likewise applies, for example, to the substantive criteria of exclusion and deportation of non-citizens, the mandatory detention of inadmissible non-citizens and of some non-citizens subject to removal, the limitation of judicial review of removal decisions, and the retroactive application of new grounds for removal. See Gerald L. Neuman, Strangers to the Constitution: Immigrants, Borders, and Fundamental LAw 14 (1996); Barbara Hines, An Overview of U.S. Immigration Law and Policy Since 9/11, 12 Tex. Hisp. J.L. \& Pol'y 9, 11 (2006); T. Alexander Aleinikoff, Semblances of Sovereignty: The Constitution, the State, and American Citizenship 174-75 (2002). Daniel Kanstroom captures the scope of constitutional deference with respect to the deportation system:

Suppression of evidence that may have been seized in violation of the Fourth Amendment will be impossible in most cases. The noncitizen will not be read "Miranda" rights. ... . If he believes he has been singled out due to race, religion, or political opinion, he will generally not be able to raise a "selective prosecution" defense. He will never have the right to a jury trial. If he has a formal hearing before an immigration judge, he will have certain due process rights: to be heard, to examine evidence, and to receive a written decision .... If he wants to appeal the immigration judge's decision, he may face incarceration during the length of that appeal-which could easily be years. He may then receive a summary decision made by a single member of the understaffed and overwhelmed Board of Immigration Appeals produced after a ten-minute review of his case.

Daniel Kanstroom, Deportation Nation: Outsiders in American History 4 (2007).

14 This liberalization includes, most notably, the abolition of national origins quotas in the Immigration and Nationality Act of 1965, Pub. L. No. 89-236, 79 Stat. 911.

is See, e.g., NEuman, supra note 13, at 13 (describing the "immigration anomaly"); LucY E. Salyer, Laws Harsh as Tigers: Chinese Immigrants and the Shaping of Modern IMMIGRATION LAW 245 (1995) (observing that immigration is "alienate[d] . . . from other branches of public law"); Peter H. Schuck, Citizens, Strangers, and IN-Betweens: EsSAYS ON IMMIGRATION AND CITIZENSHIP 19 (1998) (characterizing immigration as a legal "maverick" and "wild card"); Hiroshi Motomura, The Curious Evolution of Immigration Law: Procedural Surrogates for Substantive Constitutional Rights, 92 Colum. L. Rev. 1625, 1704 (1992) (noting the "singularity" of immigration). 
ceptionalism-the long-standing and categorical equation of immigration regulation with the conduct of foreign affairs and national security.

The existing scholarship on the origins of the plenary power doctrine does not account convincingly for either the Court's precipitous abandonment in 1889 of its long-standing Commerce Clause framework or the remarkable historical durability of the inherent sovereignty model. This explanatory deficit stems primarily from modern scholars' failure to appreciate the enormous political and ideological stakes that immigration regulation carried for late nineteenth-century judges and policymakers. As a result, the scholarship consistently understates both the historical doctrinal importance and the cultural and political resonance of the "national security rationale" for immigration exceptionalism. ${ }^{16}$

${ }^{16}$ The fact that the Court first endorsed the plenary power doctrine in the context of Chinese exclusion, in an opinion notable for its explicit and sensational condemnation of the Chinese as a race, has led some leading commentators to suggest that the doctrine was animated primarily by the virulent anti-Chinese racism that pervaded late nineteenth-century American political culture. See, e.g., Kanstroom, supra note 13, at 95-130; Neuman, supra note 13, at 119, 123-24; Stephen H. Legomsky, Immigration Law and the Principle of Plenary Congressional Power, 1984 Sup. CT. REv. 255, 289. Within this framework, the Court's invocation in the Chinese Exclusion Case and elsewhere of Chinese laborers' "aggression" against the nation's "peace and security" reads either as racist hyperbole, or as an "analogy" to war wielded tactically by the Court in order to justify the same extraordinary judicial deference that Congress and the Executive enjoy with respect to foreign affairs and national security. See NEUMAN, supra note 13, at 136 (discussing the "analogy between immigration and invasion"). Although anti-Chinese sentiment was distinctive both in its intensity and its policy consequences - specifically, the near-categorical exclusion of Chinese immigrants-the basic terms of that sentiment differed little from the racialist nativism directed at European immigrants during the same period. See infra notes 151-172 and accompanying text.

Historian Lucy Salyer argues that Chinese immigrants' remarkably successful legal resistance to the exclusion regime "provides a concrete explanation for the divergence of immigration law from other branches of administrative law." SALYER, supra note 15, at xvii. Salyer makes a persuasive case that federal judges' frustration over ineffective enforcement of the Chinese Exclusion Act triggered the Court's adoption of the plenary power doctrine. However, her account cannot explain why the national security rationale, and the broader principle of extra-constitutionality, were extended almost immediately to the regulation of European immigration as well.

Other leading scholars do recognize that the origins of immigration exceptionalism extend beyond Chinese exclusion to a broader late nineteenth-century critique of immigration. Several important studies have pointed specifically to the surge of racialist nativism in the final decades of the nineteenth century to explain the triumph of "nationalistic, exclusionary values" over "the earlier individualistic ideology of traditional liberalism." SCHUCK, supra note 15, at 48. See also Aleinikoff, supra note 13, at 26 (describing the construction of an "Anglo-Saxon polity" in order to consolidate the "nationness of the United States"); RoGERs M. Smith, Civic Ideals: Conflicting Visions of Citizenship in U.S. History 347 (1997) (describing the "repudiation of Reconstruction egalitarian and inclusiveness" in favor of inegalitarian "ascriptivism"); Sarah H. Cleveland, Powers Inherent in Sovereignty: Indians, Aliens, Territories, and the Nineteenth Century Origins of Plenary Power Over Foreign Affairs, 81 TEx. L. REv. 1, 263 (2002) (maintaining that the "racist and nationalist views of the day go far in explaining the substantive outcomes reached in the inherent powers decisions"). Each of these works, however, employs an overly static model of race and racism that forecloses inquiry into the historical process through which the racial meaning ascribed to immigrants took shape. Interrogating that process enables us to better appreciate the underlying stakes of immigration regulation for the original architects of the plenary power doctrine, and 
This Article instead places the national security rationale at the center of its historical analysis. I argue that the plenary power doctrine was borne of an urgent sense of national peril, the terms of which most contemporary policymakers, judges, and scholars would reject. The original, late nineteenth-century architects of the plenary power doctrine believed that unchecked immigration had created a state of national emergency. In response, the Supreme Court fashioned an immigration power adapted not to the regulation of labor, or economic dependency, or crime-issues that, then as now, characterize most immigration lawmaking - but rather to the defense of the nation against foreign aggression. In so doing, the Court radically transformed the prevailing theory of national sovereignty from a domain of federal authority defined by specific, constitutionally enumerated powers, to one unmoored from the Constitution, "essential to self-preservation," 17 and reserved exclusively for "the political department of the government."18

Although the modern federal immigration power made its judicial debut in the Chinese Exclusion Case,$^{19}$ its historical origins in fact lie largely beyond Chinese exclusion, in a much broader contemporaneous critique of (mostly European) immigration. I argue that immigration exceptionalism is the product of a deep antagonism between the nation's republican politicaleconomic principles and the unprecedented social and economic dislocations wrought by the industrialization of the northern economy. For most of its history, the United States' relative liberality toward immigration was rooted in Americans' broad confidence that an open continent, easy access to land, and exposure to republican political values and institutions would assimilate all comers. Republicans were not born; rather, they were made. This confidence underwrote a broad consensus, well into the post-Civil War era, that immigration was an invaluable economic asset to the nation, and that the vast majority of immigrants were desirable additions to the national polity. The problems associated with immigration-destitution, dependency on public support, crime, and disease-were generally understood to fit comfortably within the regulatory province of traditional state police authority and, by mid-century, federal commerce authority. During the first one hundred years of the nation's history, the immigration power was thus defined fundamentally by reference to the specific purpose of the regulation at issue. State police authority reflected an understanding of immigrants primarily as individuals who may, like anyone else, be or become paupers or criminals; federal commerce authority likened immigrants to international commercial goods. In both cases, immigrants' foreignness per se was incidental, or at least secondary, to defining the power itself.

to gain a richer, more historically accurate understanding of the national security rationale for immigration exceptionalism.

${ }^{17}$ Nishimura Ekiu v. United States, 142 U.S. 651, 659 (1891).

${ }^{18}$ Id.

${ }^{19}$ The Chinese Exclusion Case, 130 U.S. 581, 609 (1889). 
In the last third of the nineteenth century, however, this vision collided with the economic and social realities of industrialization, including the deskilling of labor, the triumph of the wage system, increasingly intense wage competition, and the appearance of sustained widespread poverty in the nation's cities. In response, contemporaries developed a diagnosis of the nation's social and economic ills that centered less on these broad structural economic forces than on immigrants and immigration. A diverse range of policymakers, judges, labor spokesmen, and economists identified as the culprit a phenomenon that they called the "crisis of foreign pauper labor."20 In contrast to "foreign paupers," whose economic dependency had long drawn the attention of state lawmakers and charity administrators, foreign pauper laborers offended through an excess of economic competitiveness. Their willingness to work for virtually any wage, critics charged, degraded the labor market, robbed "American" workers of a "civilized" standard of living, and threatened to destroy the very foundation of the nation's exceptionalist identity - the respectability, personal independence, and political virtue of the citizenry. ${ }^{21}$ The quality of American citizenship, and ultimately, the very future of the republic, appeared to lie in the balance.

Critics of European and Chinese immigration alike routinely invoked the increasingly resonant logic of heredity and race. Pauper laborers' low standards of living, willingness to work for starvation wages, and inability to assimilate politically, they charged, were the product of their ingrained racial dispositions. Without the requisite economic conditions and racial material, critics argued, exposing immigrants to republican political culture held, by itself, little value as a force of assimilation. Contemporaries thus reimagined the American polity as a social and political body whose health depended less on the vitality of its political and economic values and institutions than on the collective natural endowments of its constituent members. In short, republicans were born, rather than made. Under this view, the future of the republic could be preserved only by repelling the foreign menace that threatened to degrade it. ${ }^{22}$ In response, the Supreme Court, in concert with Congress and a host of influential policy critics, forged the immigration power into an instrument of national self-defense, to be deployed against "invading armies" of politically unassimilable, economically degraded, and racially suspect foreign laborers. Though such immigrants were citizens of

\footnotetext{
${ }^{20}$ See infra Part II.A

${ }^{21}$ At its core, nineteenth-century exceptionalism consisted of a shared national confidence that the combination of unlimited natural resources, free labor, and republican political values of personal independence and virtuous citizenship would enable the United States to transcend the class conflict, political strife, and widespread poverty that had plagued the nations of Europe throughout the industrial era. On the "crisis in the national ideology of American exceptionalism," see Dorothy Ross, The Origins of American Social SCIEnce 53 (1991).

${ }^{22}$ On the role of immigration regulation in mediating the conflict between the nation's republican ideals and the social and economic convulsions of the industrial era, see Matthew $\mathbf{J}$. Lindsay, Preserving the Exceptional Republic: Political Economy, Race, and the Federalization of American Immigration Law, 17 YALE J.L. \& HumaN. 181, $182-86$ (2005).
} 
ostensibly "friendly" nations, policymakers and judges reimagined them as enemy aliens. The immigration power was thus redefined in relation to its objects, as immigrants' foreignness itself came to dictate the source, locus, and scope of Congress's regulatory authority. Through this process, the Court in effect invented the "immigrant" as a distinct, and distinctly consequential, legal construct.

Although the Supreme Court in recent decades has muted some of the more severe aspects of the plenary power doctrine, ${ }^{23}$ the constitutional exceptionalism of the immigration power, as well as its core legal rationale, remain fundamentally intact. As the passages quoted from the Kim decision indicate, the Court continues to define federal authority over immigration with reference to national sovereignty in matters of war, foreign affairs, and the preservation of republican government. ${ }^{24}$ It perpetuates the wholesale presumption that all laws regulating immigration are part and parcel of the conduct of national security, even though the social and political judgments that historically appeared to justify such a presumption-specifically, the Court's literal equation in the late nineteenth century between foreign pauper labor and foreign aggression-would strike most contemporary policymakers and judges as anachronistic. ${ }^{25}$

\footnotetext{
${ }^{23}$ See Zadvydas v. Davis, 533 U.S. 678, 695 (2001) (holding that despite the "plenary" nature of legislative and executive power over immigration, "that power is subject to important constitutional limitations"); Motomura, supra note 13, at 1628 (arguing that in recent decades "procedural due process has served in a significant number of cases as a 'surrogate' for the substantive judicial review that the plenary power doctrine seems to bar"); see also infra note 245 .

${ }^{24}$ The executive branch, in particular, continues to stress the national security rationale for judicial deference toward immigration policymaking and enforcement. $C f$. infra note 240 (describing rationales for judicial deference to both political branches in the immigration context). Since the terrorist attacks of September 11, 2001, the government has used its broad authority over immigration to selectively detain, and often deport, thousands of immigrants. Perhaps most strikingly, in 2002 the Department of Justice implemented the National Security Entry-Exit Registration System, requiring all nonimmigrant male aliens over sixteen years old from twenty-five predominantly Arab and Muslim countries to register with the INS within thirty days, and to report annually to an immigration officer. Registration of Certain Nonimmigrant Aliens from Designated Countries, 67 Fed. Reg. 67,766 (Nov. 6, 2002). The government never filed a criminal terrorism charge against any registrant, and after much criticism abandoned the program. See Hines, supra note 13, at 15-17. On the targeting of Arabs and Muslims within the U.S. since 9/11, see David Cole, Enemy Aliens: Double Standards and Constitutional Freedoms in the War on Terrorism (2003).

${ }^{25}$ Readers familiar with the commentary of prominent contemporary immigration critics such as former CNN news broadcaster Lou Dobbs, commentator Patrick Buchanan, or Congressman Tom Tancredo, among many others, may be skeptical of this claim. Dobbs, for example, routinely refers to an "illegal alien invasion" across the U.S. border with Mexico. See, e.g., Lou Dobbs Tonight (CNN television broadcast Mar. 21, 2005) (transcript available online at http://transcripts.cnn.com). And Buchanan, never one for subtlety, published a book in 2006 titled State of Emergency: The Third World Invasion and Conquest of America. First, such views, though no doubt shared by many Americans, do not represent majority opinion among policy elites or federal judges, as they did at the turn of the last century. Second, even most "mainstream" anti-illegal-immigration zealots generally do not claim that immigration per se poses an existential threat to the nation. Dobbs, for example, has suggested that he favors increasing legal immigration. See, e.g., Sam Stein, Book Exclusive: Lou Dobbs Said
} 
Part I of this Article examines state and federal authority to regulate immigration in the half-century preceding the emergence of modern immigration exceptionalism. It advances two propositions. First, early federal authority over immigration derived from Congress's constitutional power to regulate commerce with foreign nations. Second, mid-nineteenth-century judicial defenders of state regulation advocated dual theories of state authority, grounded alternately in states' traditional police power, and states' status under international law as independent sovereigns endowed with an expansive power of self-defense. The latter theory partially anticipated the inherent congressional power framework embraced by the Supreme Court in the plenary power cases, but did so within a constitutionally circumscribed understanding of governmental sovereignty. Part II analyzes the creation of the modern federal immigration power as a form of authority "inherent in sovereignty and essential to self-preservation," ${ }^{26}$ and as such buffered against most judicially enforceable constitutional constraints. It argues that the historical key to modern immigration exceptionalism lies less in the novelty of the Court's theory of inherent sovereignty, than in the broadly shared commitment to secure the nation against "invading armies" of "foreign pauper laborers." The Article concludes by arguing, in Part III, that by denaturalizing the national security rationale for immigration exceptionalism, the historical analysis developed in Parts I and II functions as an historical critique of the contemporary immigration power. If the plenary power doctrine is to remain the governing framework for immigration regulation, I suggest, it should at the very least be supported by a legal rationale that today's policymakers and judges recognize as legitimate.

\section{Before Immigration Exceptionalism: Sovereignty and Commerce in the Nineteenth Century}

There exists neither an explicit constitutional basis for a federal immigration power nor any evidence that the Framers contemplated one. ${ }^{27}$ Indeed, in the half century preceding the Supreme Court's adoption of the plenary power doctrine in 1889, Supreme Court justices, legislators, and other commentators engaged in a protracted debate over the source, scope, and locus of the authority to regulate immigration. This Part advances two key propositions. First, in the middle decades of the nineteenth century, both advocates and critics of a robust federal immigration power understood congressional authority to regulate immigration to derive from the Commerce Clause. Second, judicial defenders of state authority simultaneously advocated two distinct theories. Their primary theory placed the regulation of immigration alongside the regulation of public health, safety, morals, and

He'd Be Happy to Triple Number of Legal Immigrants, Huffington Post, May 28, 2008 , http://www.huffingtonpost.com/2008/05/28/book-exclusive-lou-dobbs_n_103852.html.

${ }^{26}$ Nishimura Ekiu v. United States, 142 U.S. 651, 659 (1891).

${ }^{27}$ See Cleveland, supra note 16 , at $81-82$. 
welfare, under the general police power reserved to the states by the Constitution and through which state and local governments regulated many aspects of public and commercial life throughout the nineteenth century. Crucially, the scope of such authority was defined with reference to the purpose of the regulation at issue, rather than the foreignness of the persons upon whom the regulation acted. Their second theory of state authority imagined states as independent sovereigns, akin to nations and endowed by international law with the power to defend their citizenries against foreign encroachment.

Although there is a considerable body of scholarship addressing the origins of the federal immigration power, most existing accounts either omit discussion of the antebellum cases, ${ }^{28}$ or alternatively interpret them as mere antecedents to the modern era of immigration exceptionalism..$^{29}$ This Part proposes, by contrast, that the Court's development in the mid-nineteenth century of a theory of governmental sovereignty derived from international law and defined by the foreignness of its regulatory objects foreshadowed the theory of inherent federal sovereignty adopted decades later in the plenary power cases. ${ }^{30}$

\section{A. "Free Immigration" in the Young Republic}

For nearly a century following the nation's founding, American immigration policy reflected a deep faith among political leaders, judges, and other men of affairs that the health of the republic would be secured for all time by a vast, open frontier and robust constitutional democracy. The singular combination of limitless natural resources and republican institutions

${ }^{28}$ See, e.g., AlEINIKOFF, supra note 13 (omitting discussion of the federal immigration power before the Chinese Exclusion Case); Legomsky, supra note 16 (same); Louis Henkin, The Constitution and United States Sovereignty: A Century of Chinese Exclusion and Its Progeny, 100 HARv. L. Rev. 853, 855 (1987) (claiming that there was "little occasion" before the last third of the nineteenth century "to probe the sources of the federal power to control immigration and regulate aliens").

${ }^{29}$ See, e.g., Neuman, supra note 13, at 44 (identifying in the mid-nineteenth-century cases a counter-story about state power, to the "usual narrative of immigration law history" as an inevitable march toward full federalization); Mary Sarah Bilder, The Struggle over Immigration: Indentured Servants, Slaves, and Articles of Commerce, 61 Mo. L. REv. 743, 751 (1996) (arguing that the Court was unable to reach consensus on the nature of Congress's commerce authority over immigration for most of the nineteenth century because the politics and legal culture of slavery prevented some Justices from accepting that immigrants could be "articles of commerce" for the purpose of Commerce Clause analysis).

${ }^{30}$ In her sweeping history of the nineteenth-century origins of Congress's plenary power over foreign affairs, Sarah Cleveland notes briefly that dissenting Justices in the Passenger Cases advanced arguments for state authority over immigration similar to those later embraced by the Court "in support of an inherent national immigration power." Cleveland, supra note 16, at 105. Due to the remarkably ambitious scope of her study, however-it investigates the development of inherent congressional authority over not only immigration, but also Indian tribes and the territories-Cleveland cannot address in any detail the nineteenth-century precursors to modern immigration exceptionalism, including the state police power and international law origins of the national "power of self-preservation." Id. (citing Smith v. Turner (The Passenger Cases), 48 U.S. 283, 470 (1849) (Taney, C.J., dissenting)). 
would not only ensure the relative economic and political equality of its white, male, propertied citizens; it would spare the young nation the systemic poverty, class conflict, political instability, and social decay that plagued Europe. Not least, it would literally transform all comers into republican citizens. ${ }^{31}$ " [C]ontrary to European visions of degeneracy," writes the political scientist Aristide Zolberg, early Americans believed that "the American environment was imbued with regenerative powers verging on the miraculous .... Inclusion itself endowed newcomers with a republican soul." 32

This broad confidence in economic and political assimilation sustained a consensus well into the post-Civil War period that immigration was an invaluable national economic asset, and that the vast majority of immigrants were desirable additions to the American polity. As Carl Schurz, a leading light in the young Republican Party, explained to a Boston audience in 1859, the "American nationality" necessarily "incorporates the vigorous elements of all civilized nations on earth." ${ }_{33}$ Although Schurz granted that the "Anglo-Saxon spirit" had served as the nation's traditional "locomotive of progress," he also maintained:

\footnotetext{
${ }^{31}$ See Lindsay, supra note 22, at 191-99. From the earliest years of the republic, American political elites developed a theory of cultural and political assimilation that placed enormous stock in the power of political inclusiveness and easy access to land to transform foreigners into patriotic republicans. In 1787, Tench Coxe, a prominent political economist, leading Federalist, and future Assistant Secretary of the Treasury under Alexander Hamilton, explained to a gathering at Benjamin Franklin's Philadelphia home the transformative power of American institutions:
}

The sooner the new citizens are fully incorporated, with the society to which they accede, the sooner they become useful members; they then grow attached to their new country: they consider themselves as part of it: they adopt the opinions and affections of their new brethren, and soon forget they have adopted them, and imagine they are natural.

Tench Coxe, An Enquiry into the Best Means of Encouraging Emigration from Abroad, Consistently with the Happiness and Safety of the Original Citizens (Apr. 20, 1787), in HistoriCal Aspects of THE Immigration Problem 706 (Edith Abbott ed., 1926). The assimilationist model of American citizenship remained more or less ascendant throughout the first two thirds of the nineteenth century. Missouri Congressman Willard Hall neatly encapsulated the prevailing mid-century understanding of the transformative power of land and republican institutions: were the nation to "induce the foreign immigrant to make his home in the West" by providing easy access to land, Hall argued, it would

secure his attachment and fidelity to our institutions. As soon as he finds himself in possession of a home of his own, and occupying a position that makes him a free man-free from the control, direction, and oppression of a superior, he will and must feel proud of his American citizenship ... and his study will be to discharge all the duties of a good and faithful citizen ....

Cong. Globe, 32nd Cong., 1st Sess. 438 (1852), reprinted in Historical Aspects of the Immigration Problem 780 (Edith Abbott, ed., 1926).

${ }^{32}$ Aristide R. Zolberg, A Nation by Design: Immigration Policy in the Fashioning OF AMERICA 84 (2006).

${ }^{33}$ Carl Schurz, True Americanism, Address at Faneuil Hall (Apr. 18, 1859), in IMMIGRAtion and the American Tradition 121, 121 (Moses Rischin ed., 1976). 
[T] his locomotive would be of little use to the world if it refused to draw its train over the iron highway and carry its valuable freight towards its destination; that train consists of the vigorous elements of all nations; that freight is the vital ideas of our age; that destination is universal freedom and the ideal development of man. ${ }^{34}$

In Schurz's vision, economic development fueled by immigrant labor strode aside political freedom in the great march of human progress.

This worldview directly shaped the regulation of immigration-or, more specifically, the relative lack of regulation-during the nation's first century. Before the 1870 s, the national government never acted to exclude any class of immigrants, and the only two federal regulations adopted during that period-the Passenger Acts of $1819^{35}$ and $1847^{36}$ - were directed toward improving the conditions of passage by reducing the number of passengers per ship. Nor was the spirit of welcome limited to Europeans. As late as 1868 - a mere fourteen years before Congress adopted the first Chinese Exclusion Act-the United States and China entered into the Burlingame Treaty, pledging to afford each other's citizens the same privileges and immunities as citizens of the most favored nation, and affirming "the inherent and inalienable right of man to change his home and allegiance, and also the mutual advantage of the free migration and emigration of their citizens and subjects . . .."."37

To be sure, neither Americans' support for liberal immigration, nor their confidence in the assimilability of all immigrants went unchallenged. Antiimmigrant sentiment directed at a recent influx of Irish (especially Catholic) immigrants spiked in the 1850 s, fueling the brief electoral success of the nativist Know Nothing Party. And while the United States certainly valued Chinese immigrants for their labor, political inclusion was another matter. Chinese immigrants remained ineligible for naturalization throughout the nineteenth century and the first half of the twentieth. ${ }^{38}$ In addition, while the

${ }^{34}$ Id. at $123-24$.

35 Steerage Act of March 2, 1819, ch. 46, 3 Stat. 488

${ }^{36}$ Passenger Act of Feb. 22, 1847, ch. 16, 9 Stat. 127 (repealed 1855).

${ }^{37}$ Treaty of Trade, Consuls, and Emigration, U.S.-China, July 28, 1868, 16 Stat. 739, 740 [hereinafter Burlingame Treaty]. That same year, the Expatriation Act linked this right of free migration to the 'Tnited States' general policy of welcoming immigrants: "[T] expatriation is a natural and inherent right of all people, indispensable to the enjoyment of the rights of life, liberty, and the pursuit of happiness; and . . . in the recognition of this principle this government has freely received emigrants from all nations, and invested them with the rights of citizenship ....." Expatriation Act of July 27, 1868, ch. 249, 15 Stat. 223, 223.

${ }^{38}$ The Naturalization Act of 1790 restricted naturalization to "free white persons." Naturalization Act of 1790, ch. 3, 1 Stat. 103, 103. Chinese and other nonnative born "asiatics" were excluded from American citizenship until the Immigration Act of 1952 lifted the racial ban. As Reginald Horsman demonstrates, by the middle decades of the nineteenth century, there existed general skepticism regarding the suitability of nonwhite "races"-including Mexicans in the southwest and Native Americans throughout the continent, as well as African Americans and Chinese immigrants-for republican government. See generally REGiNALD 
Passenger Acts certainly improved the welfare of immigrants, the Congresses that enacted those statutes clearly hoped and expected that the measures they implemented would also check the flow of immigration during economic downturns. ${ }^{39}$ Notwithstanding such reservations, however, the problems associated with immigration-destitution, dependence on public support, crime, disease, and prostitution-were broadly viewed as exceptions to an overwhelmingly beneficial policy of liberality.

Most importantly for regulatory purposes, those problems were understood as local and discrete. As such, they fit comfortably within the province of traditional state police authority, under which nineteenth-century states and municipalities regulated all aspects of public health, safety, morals, and welfare. ${ }^{40}$ And indeed, throughout the first two thirds of the nineteenth century, the seaboard states, rather than the federal government, exercised primary authority over the landing of immigrants. For example, the state of New York-which in the mid-nineteenth century received about three quarters of the nation's immigrants-exacted from each immigrant a head tax, which it used to fund a refuge and hospital for newly landed immigrants, facilitate transportation to the interior, and even supply the most destitute immigrants with a small amount of money. Such regulations were designed and administered as much to encourage immigrants' economic independence and to protect them from the vice and deceit that was said to plague American port cities, as to defend the states receiving them against the burden of impoverished or criminal foreigners. ${ }^{41}$

\section{B. Police vs. Commerce}

The mid-nineteenth century debate over the source, nature, and locus of governmental authority to regulate immigration unfolded in two landmark Supreme Court cases-City of New York $v$. Miln $n^{42}$ and the Passenger Cases. ${ }^{43}$ This Section establishes, first, that virtually all of the participants in these cases-litigants and judges alike-acknowledged that federal authority over immigration derived from Congress's constitutionally enumerated commerce power. Second, it demonstrates that a states-rights bloc of justices mounted two distinct defenses of the states' authority to regulate immigration. The primary defense centered on the states' traditional police power, the scope of which was defined by the purpose of the regulation at

Horsman, Race and Manifest Destiny: The Origins of American Racial Anglo-SaxONISM 5-6 (1981).

${ }^{39}$ On the Passenger Acts of 1819 and 1847 as a form of "remote control" motivated by restrictionist impulses, see ZOLBERG, supra note 32 , at 112-15, 145-48.

${ }^{40} \mathrm{On}$ the pervasiveness of police regulations in the nineteenth-century United States and the reigning theory and practice of a "well-regulated society," see WILliam J. NovaK, THE People's Welfare: Law and Regulation in Nineteenth-Century America (1996).

${ }^{41}$ See Lindsay, supra note 22 , at 198-200.

${ }^{42} 36$ U.S. 102 (1837).

4348 U.S. 283 (1849). 
issue. The justices supplemented this defense with a second, more historically prescient theory of state authority that imagined states as independent sovereigns endowed by international law with the power of self-defense, and that depended explicitly on immigrants' status as noncitizens. ${ }^{44}$ These justices in effect invented the "immigrant" as a distinct, and distinctly consequential, legal construct.

The federalization of immigration lawmaking between the first federal Passenger Act in 1819 and Congress's assumption of full administrative control over the landing of immigrants in 1891 was deeply embedded in two epochal historical dynamics: slavery and emancipation, and the industrialization of labor. First, the debate among the justices over the authority to regulate immigration unfolded in the shadow of sectional political conflict over slavery. Pro-slavery states' rights advocates denied that immigrants could be "articles of commerce" because this view implied that Congress might also possess the constitutional authority to regulate other human articles of commerce-namely slaves. ${ }^{45}$ Second, the federalization of immigration regulation was shaped by a wholesale political and cultural reconstruction of adult male economic dependency. In response to a host of economic and social dislocations associated with the industrial reorganization of labor, nineteenth-century Americans reconceived "pauperism" from an individual moral failing, the burden of which was appropriately borne by states and municipalities, to an intractable quality of "unfit" nationalities and races that had overflowed the bounds of locality to pose a fundamental challenge to the nation's most cherished political and economic values. ${ }^{46}$

\section{City of New York v. Miln}

The Supreme Court first addressed the power to regulate immigration, and attempted to define the states' and the federal government's respective spheres of authority, in the 1837 case of City of New York v. Miln..$^{47}$ The case involved a challenge to an 1824 New York State law requiring the master of every vessel arriving in the Port of New York to report in writing

\footnotetext{
${ }^{44}$ This interpretation thus complicates the suggestion of some scholars that the sovereignty rationale embraced by the Supreme Court in the Chinese Exclusion Case was the critical doctrinal innovation that ushered in the modern era of immigration exceptionalism. See, e.g., Aleinikoff, supra note 13, at 12-18; Henkin, supra note 28, at 853-54.

${ }^{45}$ See Bilder, supra note 29, at 793-818.

${ }^{46}$ Part II.A, infra, describes this transformation in greater detail. In brief, in the final two decades of the nineteenth century, the problem of "foreign pauper labor" captivated policymakers and economists alike. Unlike "foreign paupers," whose economic dependency had long drawn the ire and regulatory attention of lawmakers, foreign pauper laborers offended through an excess of economic competitiveness. Through their willingness to work for virtually any wage, critics charged, foreign pauper laborers robbed "American" workers of the income required to secure for their families a "civilized" standard of living, thereby not only degrading the labor market, but threatening to destroy the very fabric of the republic-the respectability, personal independence, and political virtue of the citizenry. See also Lindsay, supra note 22 , at $220-23$.

4736 U.S. 102 (1837).
} 
the name, birthplace, last legal settlement, age, and occupation of every passenger. ${ }^{48}$ George Miln, a shipmaster convicted of violating the reporting requirement, charged that the provision was an unconstitutional regulation of foreign commerce by a state and therefore void. The Court rejected the challenge, holding that the law was not a regulation of commerce; that even if it could be thus understood, it nevertheless was valid because it did not interfere with an act of Congress; and finally, that states exercised unlimited jurisdiction within their territory, comparable to that of an independent nation.

Tellingly, both parties and all of the justices in Miln agreed that the commerce power afforded Congress some measure of authority to regulate immigration. Thirteen years earlier, in Gibbons v. Ogden, ${ }^{49}$ the Court had established that Congress's power to regulate commerce with foreign nations or among the several states encompassed "navigation," irrespective of whether the object of such navigation was the transportation of goods or of persons. ${ }^{50}$ In Miln, counsel for New York conceded that the Commerce Clause afforded Congress supreme power over the transit of foreign passengers to the United States. The legal conflict instead centered on the scope and nature of authority retained by New York. To the extent that the reporting requirement was a "commercial regulation," the state acknowledged, it would be invalid if it were found to conflict with an act of Congress. ${ }^{51}$ The Court agreed that a state regulation of immigration "partaking of the nature of a commercial regulation ... would stand the test of the most rigid scrutiny ...."s2

Justice Barbour's majority opinion ${ }^{53}$ concluded that, by virtue of the act's purpose and object, it was "not a regulation of commerce, but of police; and [thus] ... passed in the exercise of a power rightfully belonging to the states." ${ }_{4}$ The "whole scope of the law," the Court explained, indicated that the legislature's purpose was "to prevent New York from being burdened by an influx of persons ... chargeable as paupers." ${ }^{55}$ Because goods, and not persons, are the subjects of commerce, Congress's commerce power did not encompass the reporting requirement. ${ }^{56}$ Even if the challenged provision "could be considered as partaking of the nature of a commercial regulation," it remained within the authority of the state so long as it avoided a direct

${ }^{48}$ Id. at 130 .

${ }^{49} 22$ U.S. 1 (1824)

${ }^{50}$ Id. at 197.

${ }^{51}$ Miln, 36 U.S. at 127.

${ }^{52} I d$. at 139.

${ }^{53}$ In the Passenger Cases, decided twelve years after Miln, Justice Wayne refuted at length Barbour's claim in Miln to have written for a majority of the Court. See The Passenger Cases, 48 U.S. 283, 429-36 (1849) (Wayne, J., concurring).

${ }^{54}$ Miln, 36 U.S. at 132.

${ }^{55}$ Id. at 133.

${ }^{56}$ See Bilder, supra note 29 , at $751,793-818$. 
"collision" with the will of Congress. ${ }^{57}$ The most recent expression of national policy - the Passenger Act of 1819—acted on passengers only "whilst on their voyage, and until they shall have landed," the Court explained. Because New York's reporting requirement applied to passengers who had already landed-that is, who "have ceased to be passengers"- the law's "operation only begins where that of the laws of congress end." 58 The fact that the persons who were the objects of the regulation were recently landed aliens was merely incidental to the state's authority to enact the law.

The majority then added a decidedly outward-looking gloss on the state's power of internal police. The Court's decision turned not only on its specific resolution of the boundary dispute between Congress's commerce authority and the police power of the state, but also on New York's status as an independent sovereign under the law of nations. The Court reasoned that with respect to aliens, states were, like nations, endowed by international law with the absolute power to defend their territorial integrity against foreign encroachment. In support of this theory, the Court advanced a series of "impregnable positions":

That a state has the same undeniable and unlimited jurisdiction over all persons and things, within its territorial limits, as any foreign nation; where that jurisdiction is not surrendered or restrained by the constitution of the United States. That, by virtue of this, it is ... [the] solemn duty of a state, to advance the safety, happiness and prosperity of its people, and to provide for its general welfare . . . where the power over the particular subject, or the manner of its exercise is not surrendered or restrained .... That all those powers which relate to merely municipal legislation, or what may . . . properly be called internal police, are not thus surrendered or restrained; and that, consequently, in relation to these, the authority of a state is complete, unqualified, and exclusive. ${ }^{59}$

New York's authority to adopt the challenged reporting requirement, the Court suggested, lay in its duty to defend the citizenry against an external threat. As the nation's principle port of entry, New York was "exposed to the evil of thousands of foreign emigrants arriving there, and the consequent danger of her citizens being subjected to a heavy charge in the maintenance of those who are poor."60 "It is the duty of the state to protect its citizens from this evil," the Court declared. ${ }^{61}$ Notwithstanding the Court's decision

\footnotetext{
${ }^{57}$ Miln, 36 U.S. at 138. The Court further suggested that even coterminous state and federal regulations may not qualify as a true "collision," insofar as such regulations may be "scarcely .. . distinguishable" from one another yet still "flow from distinct powers." Id. at 137.

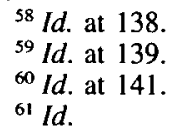


to cast New York's authority specifically in terms of its power to repel an external threat, as well as its invocation of international law as a source of such authority, the scope of the state's power remained confined to matters "relat[ed] to merely municipal legislation." 62

To explain the "origin and character of this power," the Court invoked not the text of the Constitution or the history of the United States' founding, but the law of nations. ${ }^{63}$ By way of illustrating the "truism" that New York "possessed the power to pass this law before the adoption of the constitution of the United States," Justice Barbour turned to the international law authority Emer de Vattel. ${ }^{64}$ Vattel explained: "The sovereign may forbid the entrance of his territory, either to foreigners in general, or in particular cases, or to certain persons, or for certain reasons, according as he may think it advantageous to the state." 65 This passage, from Vattel's 1758 treatise, The Law of Nations or the Principles of International Law, would become a favorite of jurists concerned about federal usurpation of state police authority. Justice Barbour's opinion in Miln thus embraces a naturalistic theory of governmental sovereignty derived from international law. "There can be no mode in which the power to regulate internal police could be more appropriately exercised," the Court concluded, than protecting the state's citizens against oppression by foreign paupers. ${ }^{66}$ This was a power that was both "complete, unqualified, and exclusive"-or "plenary," in the ordinary legal sense of that term-yet restrained in scope by the U.S. Constitution. ${ }^{67}$

\section{The Passenger Cases}

The relative authority of the states and the federal government to regulate immigration, as well as the nature of the "sovereignty" from which such authority flowed, received its fullest elaboration in the 1849 Passenger Cases. ${ }^{68}$ The case consolidated challenges to New York and Massachusetts laws, each requiring the master of every vessel arriving from a foreign port to pay a modest head tax for each passenger, to be used to fund a marine hospital and to support "foreign paupers," respectively. ${ }^{69}$ In a decision consisting of eight separate opinions totaling nearly 300 pages, the Court held that the taxes were an unconstitutional regulation of foreign commerce.

Four members of the five-justice majority struck down the head taxes on the ground that the provisions directly collided with the will of Con-

${ }^{62} \mathrm{Id}$. at 137. See supra text accompanying note 59.

${ }^{63} \mathrm{Id}$. at 132 .

${ }^{64} \mathrm{Id}$.

${ }^{65}$ Id. The Court continued, "Since the lord of the territory may, whenever he thinks proper, forbid its being entered, he has, no doubt, a power to annex what conditions he pleases, to the permission to enter." Id.
${ }^{66} \mathrm{Id}$. at 141.
${ }^{67}$ See supra note 6.
${ }^{68} 48$ U.S. 283 (1849).
${ }^{69} I d$. at 286. 
gress. $^{70}$ They interpreted the relative absence of federal regulation as an expression of Congress's affirmative policy of promoting "free immigration," rather than, as the dissenters argued, either a reflection of congressional indifference or an invitation to the states to legislate. "From the first day of our [nation's] separate existence," Justice Catron reasoned, "has the policy of drawing hither aliens, to the end of becoming citizens, been a favorite policy of the United States, . . . cherished by Congress with rare steadiness and vigor."71 No single state, he concluded, can "claim the power of thwarting by its own authority the established policy of all the States united."72

The challenged regulations exceeded the bounds of state authority precisely because they encompassed persons who posed no threat to public health, morals, or welfare. The justices pointed specifically to the failure of the New York and Massachusetts taxes to discriminate between would-be dependents, on the one hand, and the vast majority of immigrants whose settlement the United States sought to encourage, on the other. The majority judged "fallacious" the states' argument that because a state may exclude paupers and lunatics under its police power, "therefore she may exclude all persons, whether they come within this category or not." " "[S]he may ex-

${ }^{70} \mathrm{Id}$. at 410-64 (concurring opinions of Wayne, Catron, McKinley, and Grier, JJ.). The fifth member, Justice McLean, insisted that because the Constitution vested the authority to regulate foreign commerce exclusively with Congress, it thereby also prohibited any and all state regulation touching on the subject. See id. at 392-410.

${ }^{71} \mathrm{Id}$. at 440 . This interpretation of the relative scarcity of federal regulation, in turn, reflected each justice's assessment of the actual economic and political virtues of immigration, read through the lens of his republican worldview. As Catron noted, through the national policy of liberal immigration "our extensive and fertile country has been . . . filled up by a respectable population ... that is easily governed and usually of approved patriotism." Id. In light of its material benefit, and " $[\mathrm{k}]$ eeping in view the spirit of the Declaration of Independence with respect to the importance of augmenting the population of the United States," Congress had frequently passed laws "to facilitate and encourage more and more the immigration of Europeans into the United States for the purpose of settlement and residence." Id. After reviewing various federal reporting requirements and other provisions enacted for the benefit of immigrants, Catron observed:

It is evident that, by these repeated and well-considered acts of legislation, Congress has covered, and has intended to cover, the whole field of legislation over this branch of commerce. [A]cting in the spirit of all our history and all our policy, it has opened the door widely and invited the subjects of other countries to leave the crowded population of Europe and come to the United States.

Id. at 442 .

${ }^{72}$ Id. at 443 . Justice Grier similarly reasoned:

The United States have, within and beyond the limits of these States, many millions of acres of vacant lands. It is the cherished policy of the general government to encourage and invite Christian foreigners of our own race to seek an asylum within our borders, and to convert these waste lands into productive farms, and thus add to the wealth, population, and power of the nation. Is it possible that the framers of our Constitution have committed such an oversight, as to leave it to the discretion of some two or three States to thwart the policy of the Union, and dictate the terms upon which foreigners shall be permitted to gain access to the other States?

Id. at 461 (Grier, J., concurring).

${ }^{73}$ ld. at 463 (Grier, J., concurring). 
clude putrid and pestilential goods from being landed on her shores," Justice Grier explained, "yet it does not follow that she may prescribe what sound goods may be landed, or prohibit their importation altogether." 74 Indeed, "[t]he powers used for self-defence [sic] and protection against harm cannot be perverted into weapons of offence [sic] and aggression upon the rights of others." 75 The importance of discriminating between immigrants who were fit for republican political and economic institutions and those destined to lives of pauperism and dependency would gain even greater salience in the 1870s. As Justice Grier's analysis suggests, that distinction was already taking on constitutional meaning as the Court struggled to define the boundary between commerce and police, national and local. Just as the regulation of healthy, desirable immigrants lay beyond the police power of the states, Justice Wayne explained, "[p]aupers, vagabonds and fugitives never have been subjects of rightful national intercourse, or of commercial regulations ...."76

All of the justices in the Passenger Cases, including the four dissenters, agreed that federal authority to regulate immigration derived from Congress's constitutional power to regulate commerce. For the majority, however, and particularly for Justice Wayne, the Commerce Clause was more than the formal, constitutionally enumerated locus of the federal immigration power. It was equivalent to national sovereignty itself. Just as the Miln Court had invoked the law of nations to define the nature and scope of New York's territorial authority, so did Wayne in the Passenger Cases view federal sovereignty through the lens of eighteenth-century international law. In light of the framers' familiarity with "the many valuable works upon trade and international law," he wrote, such knowledge "may well be invoked to measure the constitutional power of Congress to regulate commerce."77 Wayne quoted Georg Friedrich de Martens' 1789 treatise, Law of Nations, explaining that such a power included the nation's right "to exercise freely its sovereign power over the foreigners living in its territories."78 The states' "erroneous proposition" that they possess "unlimited discretion ... to determine what persons shall reside in it," Wayne continued, arose from their failure to recognize that "a part of the supreme police power of a nation is identical . . . with its sovereignty over commerce. Or, more properly speaking, the regulation of commerce is one of those particular rights collectively placed in the hands of the sovereign for the good of the State."79

While supporters of a robust (if dormant) federal commerce power prevailed in the Passenger Cases, in important respects the three dissenting

${ }^{74} \mathrm{Id}$.

${ }^{75} \mathrm{Id}$.

${ }^{76} \mathrm{Id}$. at 426 (Wayne, J., concurring).

$77 \mathrm{Id}$. at 416.

${ }^{78}$ Id. (citing Georg Friedrich de Martens, Summary of the Law of Nations (William Cobbett trans., Thomas Bradford 1795) (1789)).

${ }^{79} \mathrm{Id}$. at 427. 
opinions-by Chief Justice Taney and Justices Daniel and Woodbury-were more prescient about the future of the evolving federal immigration power. The dissenters viewed the majority's decision as an illegitimate extension of congressional authority into the traditional, sovereign domain of state police power. The consequence, they warned, was to deny the states their rightful "power of self-preservation"80 against an encroaching European "mass of pauperism and vice." 81 In response, they elaborated an ambitious account of powers inherent in state sovereignty over immigration that, paradoxically, foreshadowed a theory of federal sovereignty more absolute and exclusive than any of the participants in the Passenger Cases could have imagined.

The dissenters advanced two distinct but interconnected propositions. First, they argued that the challenged statutes were textbook examples of traditional state police authority. They pleaded for a bright line of demarcation between what they considered essentially local matters of internal police and the wholly separate federal domain of commerce-a line, they urged, that should be drawn according to the regulatory purpose of the provision. The purpose of the challenged head taxes, explained Justice Woodbury, was to indemnify the states "against the ruinous burdens which would otherwise be flung upon them by the incursions of paupers from abroad . . . ."82 Like most mid-century Americans, the dissenters understood economic dependency as a quintessentially local issue. Because the challenged head taxes were "part of the pauper laws of the State," 83 the Chief Justice argued, they lay at the heart of the states' police power. Some subjects of legislation exhibit an "amphibious character," Justice Woodbury acknowledged, and were thus susceptible to classification variably as matters of police, taxation, or commerce. ${ }^{84}$ By contrast, "[t]hese affairs are a part of the domestic economy of States, belong to their interior policy, and operate on matters affecting the fireside, the hearth, and the altar." 85 "The design is local; the

${ }^{80} \mathrm{Id}$. at 470 (Taney, C.J., dissenting).

${ }^{81}$ Id. at 472 .

${ }^{82}$ Id. at 518 (Woodbury, J., dissenting). As Woodbury's statement suggests, the dissenters' perspective on immigration was markedly darker than the republican "free immigration" values of the majority. Taney worried that foreign shipmasters, perhaps acting "under the influence of foreign governments ... and having no common interest or sympathy with the people of the United States, ... may be far more disposed to bring away the worst and most dangerous portion of the population rather than the moral and industrious citizen." Id. at 471 (Taney, C.J., dissenting). As a consequence of the majority's decision, he continued, "this mass of pauperism and vice may be poured out upon the shores of a State in opposition to its laws, and the State authorities are not permitted to resist or prevent it." Id. at 472 . The result would be to "impose upon the industry of its citizens, the duty of supporting the immense mass of poverty and helplessness which is now pressing so heavily upon property in Europe, and which it is endeavouring to throw off." Id. at 490 . By denying states the capacity to "create a fund for the support of alien paupers," the majority had thus "compel[led] the several States to receive, and suffer to remain in association with its citizens, every person or class of persons whom it may be the policy of pleasure of the U.S. to admit." Id. at 465.

${ }^{83}$ Id. at 465 (Taney, C.J., dissenting).

${ }^{84} \mathrm{Id}$. at 545 (Woodbury, J., dissenting).

${ }^{85} \mathrm{Id}$. at $550-51$. 
object a State object, and not a foreign or commercial one," ${ }^{86}$ he explained. In marked contrast to the nationalization of "foreign pauperism" as an economic and political problem in the last third of the nineteenth century, ${ }^{87}$ Woodbury saw "nothing in the nature of much which is here connected with foreign commerce that is in its character foreign, or appropriate for the action of a central and single government." ${ }^{88}$ For the Passenger Cases dissenters, as for the Miln majority, the regulatory purpose of the law was essential, and the purpose was not immigration per se, but pauperism. The fact that the challenged taxes applied to immigrants qua immigrants was only incidental to their conceptual bifurcation of police from commerce, and state from federal.

The relative paucity of federal regulation touching on immigration represented not an affirmative expression of Congress's historical policy of promoting free immigration, as the majority had claimed, but rather an endorsement of immigration localism. Congress's "silence" with respect to "any mere local or subordinate matter within the limits of a State, though connected in some respects with foreign commerce," Woodbury insisted, did not "nullify[ ] and destroy[ ]" state authority. ${ }^{89}$ Rather, congressional silence is "an invitation for the States to legislate ... leaving it to them for the present, and assenting to their action in the matter . . .."900

The dissenters also advanced a second, more ambitious claim of state authority that was rooted in the law of nations, and which depended explicitly on immigrants' status as aliens. Specifically, they extended the Miln majority's theory that states, "as perfect original sovereignties," possessed a "right of self-preservation" encompassing the exclusion, regulation, or removal of aliens. ${ }^{91}$ Unlike in Miln, where the international law rationale served principally as gloss on, or supplement to, the state's traditional police power, in the Passenger Cases dissents it appears to operate as an independent source of state regulatory authority over immigration. Invoking Vattel, Woodbury explained that the right of sovereign states to prescribe the terms by which aliens may enter or remain within their territory, or to exclude them entirely, "finds vindication in the principles of public law the world over." ${ }^{2}$ Nor was such a power contingent on the condition of the aliens taxed or excluded:

Those coming may be voluntary emigrants from other nations, or traveling absentees, or refugees in revolutions, party exiles, compulsory victims of power, or they may consist of cargoes of shackled slaves, or large bands of convicts, or brigands, or persons with

\footnotetext{
${ }^{86} / d$. at 548.

${ }^{87}$ See infra Part II.A

${ }^{88}$ The Passenger Cases, 48 U.S. at 557 (Woodbury, J., dissenting).

${ }^{89} I d$. at 560.

${ }^{90}$ Id.

${ }^{91}$ Id. at 514 (Daniel, J., dissenting).

${ }^{92}$ Id. at 525 (Woodbury, J., dissenting).
} 
incendiary purposes, or imbecile paupers, or those suffering from infectious diseases, or fanatics with principles and designs more dangerous than either, or under circumstances of great ignorances, as liberated serfs, likely at once ... to make them a serious burden in their support as paupers, and a contamination of public morals. There can be no doubt, on principles of national law, of the right to prevent the entry of these, either absolutely or on such conditions as the State may deem prudent to impose. ${ }^{93}$

In contrast to the majority's rendering of the states' police power, powers inhering in state sovereignty need not discriminate between desirable "voluntary" immigrants, on the one hand, and diseased "imbecile paupers," on the other. Sovereign power was predicated on neither the purpose of the regulation, nor the condition of its objects. It derived, instead, from their foreignness.

The dissenters coupled this affirmative account of state sovereignty with a pointed critique of "the alleged right of Congress to regulate exclusively the admission of aliens." "Over aliens, qua aliens," Justice Daniel accurately noted, "no direct authority has been delegated to Congress by the Constitution."95 Daniel took issue particularly with the supposition that Congress possessed such authority under the law of nations, or under its delegated powers to make war or repel invasion. He did so, moreover, in terms that foreshadow with remarkable prescience the functional collapse forty years later of the distinction between alien friends and alien enemies. ${ }^{96}$ "[U]nder the law of nations," he wrote, "aliens are responsible only for national offences [sic], - offences [sic] in which their nation bears a part, they are then alien enemies."97 Similarly, "alien friends could not be the subjects of war ... nor in any sense instruments of a hostile invasion, such invasion being an operation of war." 98 As will become clear in Part II.B, Daniel's critique applies with equal or greater force to the Court's adoption in the Chinese Exclusion Case and its progeny of a federal immigration power "inherent in sovereignty and essential to self-preservation." 99

\footnotetext{
${ }^{93}$ Id. Chief Justice Taney similarly rejected the relevance to state sovereignty of any distinction between different "classes" of alien. There was "no provision in the Constitution of the United States which makes any distinction between different descriptions of aliens, or which reserves the power to the State as to one class and denies it over the other," he insisted. Further, the Supreme Court was "utterly incapable" of so discriminating. Taney queried: "How could [the Court] ascertain what had been the pursuits, habits, and mode of life of every emigrant, and how far he was liable to lose his health, and become, with a helpless family, a charge upon the citizens of the State?" Id. at 469 (Taney, C.J., dissenting).

${ }_{94}$ Id. at 509 (Daniel, J., dissenting).

${ }_{95} I d$.

${ }^{96}$ See infra text accompanying notes 201-202.

97 The Passenger Cases, 48 U.S. at 510 (Daniel, J., dissenting).

${ }^{98}$ Id.

${ }^{99}$ Nishimura Ekiu v. United States, 142 U.S. 651, 659 (1891). For the dissenters, in particular, the politics of race and slavery loomed large, as the scope of the federal commerce power directly implicated the ability of states to regulate the entry into their territory of slaves
} 


\section{The Federalization of the Immigration Power}

Congress and the Supreme Court federalized the immigration power in tandem. Between 1875 and 1891, Congress enacted a series of statutes wresting immigration policymaking, and then administrative control, from the states. ${ }^{100}$ The Court responded in turn by striking down a number of existing state regulations and upholding the new federal legislation. In the two decades preceding the Court's adoption of the plenary power doctrine, the Justices reached unanimous consensus that the transportation of immigrants to the United States constituted commerce with foreign nations, and accordingly, that Congress alone was constitutionally empowered to regulate that process. This was a form of congressional authority, moreover, that seemed to accommodate not only legislation that was explicitly commercial in nature, but also police-like regulations of the sort formerly reserved to the states, as well as the administration of foreign affairs. Notwithstanding its expansive scope, however, the federal immigration power of the 1870 s and 1880 s remained a creature of and subject to the U.S. Constitution. Finally, with the ascendancy of the commerce framework in the $1870 \mathrm{~s}$ and $1880 \mathrm{~s}$, the foreignness of immigrants' origins took on added meaning. Immigrants constituted articles of commerce with foreign nations precisely because they were transported to the United States from abroad. In contrast to the plenary power era, however, under the commerce framework it was the economic importance of immigration to the nation rather than the noncitizenship of immigrants themselves that dictated the nature and scope of congressional authority.

and free blacks. If the federal commerce power were exclusive of state regulations such as the challenged head taxes, Woodbury explained, "all the laws of Ohio, Mississippi, and many other States, either forbidding or taxing the entrance of slaves or liberated blacks, will be nullified ... ." The Passenger Cases, 48 U.S. at 567 (Woodbury, J., dissenting). Chief Justice Taney, who eight years later penned the majority opinion in Dred Scott $v$. Sandford, 60 U.S. 393 (1856), similarly worried that if the federal government could oblige states to receive immigrants, then "emancipated slaves of the West Indies have at this hour the absolute right to reside, hire houses, and traffic and trade throughout the Southern States, in spite of any State law to the contrary; inevitably producing the most serious discontent, and ultimately leading to the most painful consequences." The Passenger Cases, 48 U.S. at 474 (Taney, C.J., dissenting). See generally Bilder, supra note 29 , passim.

${ }^{100}$ See Immigration Act of $1891, \S 7$, ch. 551, 26 Stat. 1084 (codified as amended at 8 U.S.C. $\S \S 1551-74$ (2006)) (transferring sole authority to administer immigration regulations to the federal government, and creating the office of the Superintendent of Immigration under the authority of the Secretary of the Treasury); Contract Labor Act of 1885, chs. 161-64, 23 Stat. 332 (repealed 1952) (prohibiting the immigration of any foreigner who had entered into an employment contract with an American employer prior to departing his country of origin); Chinese Exclusion Act of 1882, ch. 126, 22 Stat. 58 (repealed 1943) (prohibiting the entry of Chinese laborers into the United States for a period of ten years); Immigration Act of 1882, ch. 376, 22 Stat. 214 (codified as amended at 8 U.S.C. $\$ \$ 1551-74$ (2006)) (transferring authority over the landing of immigrants from individual states to the United States Treasury Department); Page Act of 1875, ch. 141, 18 Stat. 477 (repealed 1974) (prohibiting the immigration of prostitutes, contract laborers and convicts from "China, Japan, or any Oriental country"). 


\section{The Demise of State Sovereignty}

Following the Supreme Court's decision in the Passenger Cases striking down the New York and Massachusetts head taxes, New York amended its immigration statute in an attempt to avoid the constitutional infirmity. The revised law required each ship owner or consignee to pay a $\$ 300$ bond to the New York Commissioners of Emigration-the state agency that administered the landing of immigrants at New York's Castle Garden depotfor every passenger arriving from a foreign port. Each bond was used to indemnify the state against the cost of supporting that passenger for four years, at which time it would be returned. Owners could avoid the sizeable bond, however, by instead paying a nonrefundable "commutation fee" of $\$ 1.50$ per passenger. As the state expected, owners invariably opted to pay the commutation fee. The amended law reached the Supreme Court in the 1875 case Henderson v. Mayor of New York. ${ }^{101}$

The parties' arguments reprised those in the Passenger Cases, centering on the familiar, if still constitutionally murky, distinction between commerce and police. The state added only that the "optional" nature of the challenged commutation fee distinguished it from the head tax struck down by the Court a quarter-century earlier. ${ }^{102} \mathrm{~A}$ unanimous Court rejected that argument, holding that because the "purpose and effect" of the scheme was to tax the owners of vessels for the privilege of landing foreign passengers, the provision was as much an unconstitutional tax on passengers as the statute at issue in the Passenger Cases. ${ }^{103}$

Although the Court's holding flowed predictably from the Passenger Cases, its construction of the federal immigration power did not. In the Passenger Cases, only Justice McLean had rejected outright the position that Congress and the states, as "two distinct sovereignties," possessed "concurrent power ... to regulate the same thing." ${ }^{104}$ In Henderson, by contrast, a unanimous Court concluded that all aspects of transporting foreigners to the United States constituted commerce with foreign nations, and therefore was the exclusive domain of Congress. As Justice Miller observed, since the Court held a half-century earlier in Gibbons v. Ogden that commerce with foreign nations encompassed laws concerning navigation,

the transportation of passengers from European ports to those of the United States has attained a magnitude and importance far beyond its proportion at that time to other branches of commerce. It

10192 U.S. 259 (1875). The plaintiff, a British ship owner, challenged the law as an unconstitutional regulation of foreign commerce by a state. The Court merged the case with a challenge to a similar provision of a Louisiana statute.

${ }^{102}$ The "right of paying . . . a small sum instead of giving a bond of indemnity," the state insisted, "cannot be tortured into an indirect mode of imposing a tax or duty upon the passenger as such." Id. at 265.

${ }^{103} \mathrm{Id}$. at 268 .

${ }^{104}$ The Passenger Cases, 48 U.S. at 399 (McLean, J., concurring). 
has become a part of our commerce with foreign nations, of vast interest to this country, as well as to the immigrants who come among us to find a welcome and a home within our borders. In addition to the wealth which some of them bring, they bring still more largely the labor which we need to till our soil, build our railroads and develop the latent resources of the country . . . ${ }^{105}$

Wherever immigration had fallen on the state/federal, police/commerce continuum as a matter of history, the ever-growing importance of immigrant labor to the nation's material progress had now drawn it completely and decisively within the scope of the federal commerce power. "Can it be doubted," Miller queried, "that a law which prescribes the terms on which vessels shall engage in [the transportation of foreign passengers to the United States] is a law regulating this branch of commerce?"106

Previously, some members of the Court, including several of the justices who decided the Passenger Cases, had supposed "a kind of neutral ground" 107 of commercial regulation that states could occupy so long as they did not interfere with an act of Congress. In Henderson, by contrast, the Court declared that any regulation that burdened commerce with foreign nations was necessarily national in character. ${ }^{108}$ In the regulation of immigration, at least, "neutral ground" between state and federal authority was a thing of the past. Americans' perception of the relationship of immigration to the nation's material well being had been so fundamentally transformed over the quarter-century since the Court decided the Passenger Cases, that all nine justices now explicitly acknowledged the essentially national nature of the issue.

Moreover, only the full federalization of immigration regulation, the Court reasoned, would enable the United States to act as a single, unified sovereign in its relations with foreign governments. A law that impairs immigration, Miller explained, "may properly be called international." ${ }^{109} \mathrm{He}$ continued:

It belongs to that class of laws which concern the exterior relation of this whole nation with other nations and governments .... It is ... in an eminent degree, a subject which concerns our international relations, in regard to which foreign nations ought to be considered and their rights respected, whether the rule be established by treaty or by legislation. ${ }^{110}$

\footnotetext{
${ }^{105}$ Henderson, 92 U.S. at 270.

${ }^{106} \mathrm{Id}$. at $270-71$.

${ }^{107} \mathrm{Id}$. at 272 .

${ }^{108}$ Id. at 273 .

${ }^{109} \mathrm{Id}$.

${ }^{110} I d$.
} 
Not only did the Court in Henderson firmly and unambiguously ground the federal immigration power in Congress's constitutionally enumerated commerce authority, but the Court also understood that authority specifically to encompass the foreign-affairs dimension of federal immigration policy.

On the same day it decided Henderson, a unanimous Court gave the foreign-affairs rationale for federal exclusivity even greater weight in Chy Lung v. Freeman, striking down a California bond requirement similar to the New York scheme. ${ }^{11}$ The California provision, however, applied only to specific enumerated classes of immigrants, including, among others, paupers, lunatics, and criminals, as well as "lewd and debauched women"- the class to which the Chy Lung plaintiff, a Chinese woman, had been assigned. ${ }^{12}$ The Court objected to the law's placement "in the hands of a single [commissioner]" the authority to require or commute a bond, and thus "to prevent entirely vessels engaged in a foreign trade, say with China, from carrying passengers, or to compel them to submit to systematic extortion of the grossest kind." 113 The consequences of such potential abuse extended far beyond the helplessness of even highly meritorious passengers before such a "potent commissioner." 14 "[A] silly, an obstinate, or a wicked commissioner may bring disgrace upon the whole country, the enmity of a powerful nation, or the loss of an equally powerful friend." 115 The Court was particularly troubled by the notion that a single state could provoke an international conflict for which the national government would bear responsibility. The Court asked whether the Constitution had "done so foolish a thing as to leave it in the power of the States to pass laws whose enforcement renders the general government liable to just reclamations which it must answer . . .."16 " [H] as the Constitution . . . done so foolish a thing," the Court asked, "as to leave it in the power of the States to pass laws whose enforcement renders the general government liable to just reclamations which it must answer ... ?" "The Constitution of the United States is no such instrument," the Court concluded. ${ }^{17}$ Rather, the authority to regulate commerce with foreign nations, "the responsibility for the character of those regulations, and for the manner of their execution, belongs solely to the national government." 118 "If it be otherwise," the Court concluded, "a single State can, at her pleasure, embroil us in disastrous quarrels with other nations." 119 Notwithstanding the apparent capacity of the Commerce Clause to accom-

'"' 92 U.S. 275, 276 (1875).

${ }^{112}$ Id. at 276 (internal quotations omitted)

${ }^{113}$ Id. at 278.

${ }^{114}$ Id. at 279 .

${ }^{115}$ Id. "[I]f citizens of our own government were treated by any foreign nation as subjects of the Emperor of China have been actually treated under this law," the Court insisted, "no administration could withstand the call for a demand on such government for redress." $I d$.

${ }^{116} I d$. at 280.

${ }^{11}$ Id.

${ }^{118} I d$.

${ }^{119} \mathrm{Id}$. 
modate not only federal exclusivity in immigration matters, but also a range of foreign considerations, the Court would upend this analysis a mere fourteen years later in the Chinese Exclusion Case. ${ }^{120}$

\section{The "Business of Immigration": Foreign Commerce and the Consolidation of the Federal Immigration Power}

The Court's decision in Henderson striking down New York's head money system devastated the state's ability to fund the administration of the Castle Garden depot-the "great throat" of European immigration to the United States, as it was often called. In response, New York abandoned its long-standing resistance to federal regulation and called for swift and aggressive national action. ${ }^{121}$ After several years of concerted lobbying by New York and several other seaboard states, Congress responded with the Immigration Act of 1882. ${ }^{122}$ The Act transferred authority to regulate the landing of immigrants from the states to the federal government, and empowered the Treasury Secretary to contract with state immigration commissions to examine passengers and to exclude "any convict, lunatic, idiot, or any person unable to take care of himself or herself without becoming a public charge." 123 The Act further provided that a duty of fifty cents be collected for each foreign passenger, to be paid into the United States Treasury to fund the administration of the Act, and to assist sick or destitute immigrants. ${ }^{124}$

If Henderson and Chy Lung established the exclusivity of federal authority to regulate immigration, the Supreme Court's unanimous 1884 decision in the Head Money Cases, ${ }^{125}$ upholding the 1882 Act's fifty cent per capita duty, concretized the nature and scope of that authority. The opinion of the Court-again authored by Justice Miller-reaffirmed that immigration lay squarely within Congress's commerce power. In reply to the plaintiff ship master's contention that the duty was in fact an unconstitutional direct tax, lacking in uniformity and extracted for a "purpose [that] has nothing to do with the general welfare," 126 the Court observed:

The burden imposed on the ship owner by this statute is the mere incident of the regulation of commerce-of that branch of foreign commerce which is involved in immigration. . . . Its provisions, from beginning to end, relate to the subject of immigration, and

${ }^{120}$ See infra Part II.B.

${ }^{121}$ See Lindsay, supra note 22, at 215-17.

${ }^{122}$ Immigration Act of 1882, ch. $376, \S \S 1-4,22$ Stat. 214 (codified as amended at 8 U.S.C. $\$ \$ 1551-74(2006))$.

${ }^{123} I d . \$ 2$.

${ }^{124}$ Id. $\$ 1$.

${ }^{125}$ Edye v. Robertson (The Head Money Cases), 112 U.S. 580 (1884). The Head Money Cases consolidated two challenges to the 1882 Act, both originating in New York: Edye v. Robertson and Cunard Steamship Company $v$. Robertson.

${ }^{126}$ Id. at 583 . 
they are aptly designed to mitigate the evils inherent in the business of bringing foreigners to this country, as those evils affect both the immigrant and the people among whom he is suddenly brought and left to his own resources. ${ }^{127}$

Understood as the business of bringing foreigners into the United States, all aspects of immigration were now matters of commerce. ${ }^{128}$ Gone were the Court's earlier deliberations over the boundary between "commerce" and the domain of internal police, or the distinction between foreign passengers who remained on board a ship, and those who had "mingled" with the local population. Immigration qua immigration was now the province of Congress.

As Miller's reference to the "evils" associated with immigration suggests, the opinion gave expression to the nation's increasing concern about the economic, moral, and racial fitness of the most recent European arrivals. Miller observed that the purpose of the 1882 Act "is humane, is highly beneficial to the poor and helpless immigrant, and is essential to the protection of people in whose midst they are deposited by the steamships . . .." $129 \mathrm{He}$ appeared incredulous that after the Court struck down similar state laws in Henderson, the plaintiff steamship company could now propose that Congress, too, lacked the power to impose a per capita duty on foreign passengers. To adopt that position would be

to hold that [the power] does not exist at all-that the framers of the Constitution have so worded that remarkable instrument, that the ships of all nations ... can, without restraint or regulation, deposit here ... the entire European population of criminals, paupers, and diseased persons, without making any provision to preserve them from starvation, and its concomitant sufferings . . . 130

The Head Money Cases thus completed the process that began with the Passenger Cases and accelerated in Henderson and Chy Lung of transferring authority from state legislatures to Congress. Taken together, these cases concluded the decades-long process of federalizing regulatory responsibility for the formerly "local" immigration problems of pauperism and crime. Even as the Court's emphasis on the commercial aspects of immigration pre-

${ }^{127}$ Id. at 595 .

${ }^{128}$ The Head Money Cases marked the United States' first appearance as a party in an immigration case. The government's brief relied exclusively on a theory of inherent sovereignty rooted in international law to argue that immigrants were foreclosed from challenging the constitutionality of the government's conduct-a fact that lends strong support to my broader contention that, while Chinese exclusion served as the catalyst for the Court's adoption of the plenary power doctrine, the true origins of that doctrinal development lie in a much broader critique of mostly European immigration. Brief for the United States at 2-4, Edye v. Robertson, 112 U.S. 580 (1884) (No. 754). See also Cleveland, supra note 16, at 110-11.

129 The Head Money Cases, 112 U.S. at 590-91.

${ }^{130}$ Id. at 591 . 
served a clear conceptual link to the purpose-oriented analysis of the midcentury cases, its increasing attention to the foreign affairs dimension of immigration regulation, as well as the external nature of the threat posed by "unfit" European immigrants, edged the Court closer to an immigration power defined by its application to non-citizens.

The same day that the Head Money Cases confirmed an expansive congressional authority over immigration, however, a second case, Chew Heong v. United States, ${ }^{131}$ made equally clear that such authority was limited by important judicially enforceable constraints. At issue in Chew Heong was a provision of the Chinese Exclusion Act of 1882 requiring Chinese laborers who had resided in the United States before the Act took effect, and then subsequently departed, to obtain a certificate of reentry in order to gain readmission to the country. A brief account of the Act's historical background is in order.

In 1868, the United States and China entered into the Burlingame Treaty, recognizing the "inherent and inalienable right of man to change his home and allegiance" and promising to extend to each other's citizens the same privileges and immunities as citizens of the most favored nation. ${ }^{132}$ Within less than a decade, a ferocious anti-Chinese movement led by the California Workingmen's Party had secured enough political power to rewrite the state constitution to permit a host of repressive measures, including the exclusion of Chinese workers from many types of labor, denial of the right to vote in state elections, and the forced relocation of resident Chinese into ghettos. When the federal courts invalidated most of the anti-Chinese measures on the ground that they violated the most-favored-nation provision of the Burlingame Treaty and the Equal Protection Clause of the Fourteenth Amendment, California labor and political leaders pressed aggressively for national legislation. ${ }^{133}$ President Hayes vetoed a highly restrictive bill passed by Congress in 1879 on the ground that it violated the Burlingame Treaty, but promptly sent a commission to China to renegotiate that agreement. ${ }^{134}$ The commission returned in 1880 with a new treaty permitting the United States to "regulate, limit, or suspend," though "not absolutely prohibit" the entry of Chinese laborers, ${ }^{135}$ but affirming that Chinese laborers currently present in the United States "shall be allowed to go and come of their own free will . . and shall be accorded all the rights, privileges, immunities and exemptions as . . citizens . . of the most favored nation." 136 The following year, Congress passed and President Arthur signed the Chinese

${ }^{131} 112$ U.S. 536 (1884).

${ }^{132}$ See supra note 37 and accompanying text.

${ }^{133}$ On the role of organized labor in the California anti-Chinese movement, see ALEXAN. der Saxton, The Indispensable Enemy: Labor and the Anti-Chinese Movement in California (1971).

${ }^{134}$ See SALYER, supra note 15 , at $12-15$.

${ }^{135}$ Immigration Treaty of 1880, U.S.-China, art. I, Nov. 17, 1880, 22 Stat. 826.

${ }^{136}$ Id. at art. II. 
Exclusion Act of 1882, barring the entry of Chinese laborers into the United States for a period of ten years and prohibiting Chinese laborers present in the United States ninety days before the passage of the Act from returning unless they obtained a certificate of identification prior to departure. ${ }^{137}$ After federal judges in San Francisco created a broad set of exemptions to the certificate requirement, Congress amended the statute on September 15, 1884 , clarifying that the certificate was the "only evidence permissible to establish [a] right of re-entry." 138

Chew Heong, a Chinese laborer, first arrived in San Francisco on November 17, 1880, and remained until June 18, 1881, when he departed for Honolulu. During his absence, Congress enacted the Chinese Exclusion Act of 1882 and the 1884 amendments. When Chew Heong sought readmission to the United States in September of 1884 , he was denied entry on the ground that he lacked the certificate required by the 1882 and 1884 Acts. The question before the Court was whether the certificate requirement applied to Chinese laborers who resided in the United States on the date of the 1880 treaty, but departed prior to the 1882 Act and remained outside of the United States until after the 1884 amendments. ${ }^{139}$ Chew Heong contended that the Burlingame Treaty secured for him the right to reenter, even though he had not procured "a collector's certificate for which the law, at [the] time [of his departure], made no provision."140 The government argued that such an interpretation would defeat Congress's clear intent. ${ }^{141}$.

The Court sustained Chew Heong's challenge. In a decision that stands in marked contrast with the Court's adoption of the plenary power doctrine just five years later, it held that the 1880 treaty guaranteed to Chinese laborers residing in the United States at the time of its adoption "the right[] of free ingress and egress." ${ }^{42}$ Because the strict application of the certificate requirement urged by the government would defeat that right, Justice Harlan's majority opinion read into the provision an exception for Chinese laborers who had resided in the United States but departed before the requirement took effect.

Harlan appealed to national sovereignty as a rationale for constraining Congress's authority to regulate immigration, rather than as a license for governmental power. He began his analysis by invoking the international obligations of sovereign nations:

[T] ]he court should be slow to assume that Congress intended to violate the stipulations of a treaty, so recently made with the government of another country. "There would no longer be any se-

${ }^{137}$ Chinese Exclusion Act of 1882, ch. 126, 22 Stat. 58.

${ }^{138}$ Act of July 5, 1885 , ch. 220, 23 Stat. 115,116 (1884). On the federal courts' frustration of the certificate requirement, see SALYER, supra note 15 at $18-20$.

${ }^{139}$ Chew Heong v. United States, 112 U.S. 536, 538-39 (1884).

${ }^{140} \mathrm{Id}$. at 539.

${ }^{141} I d$.

${ }^{142} \mathrm{Id}$. at 543. 
curity," says Vattel, "no longer any commerce between mankind, if they did not think themselves obliged to keep faith with each other, and to perform their promises." ... [T] [The honor of the government and people of the United States is involved in every inquiry whether rights secured by such stipulations shall be recognized and protected. ${ }^{143}$

Harlan thus rejected the government's "supposition ... that Congress, while professing to faithfully execute treaty stipulations, and recognizing ... that they secured . . . the 'right to go from and come to the United States,' intended to make its protection depend upon the performance of conditions [that were] physically impossible to perform."'144 In light of the Court's conclusion in the Chinese Exclusion Case just five years later that national sovereignty under international law serves as a blanket license for virtually unrestrained federal authority, the force Harlan afforded to the United States' treaty obligations as a check on Congress is especially remarkable. ${ }^{145}$

\section{II. "National Security" and the Birth of the Plenary POWER DOCTRINE}

Part I demonstrated that in the half-century preceding the advent of the plenary power doctrine, the federal immigration power resided exclusively in Congress's constitutionally delegated commerce power; that state and federal authority alike were premised on the purpose of a given regulation, rather than the foreignness of the persons on whom it acted; and that such authority was subject to judicially enforceable constraints. Part II explains how and why this changed. It argues that the key to modern immigration exceptionalism lies not only in the Supreme Court's elaboration of a federal authority inherent in sovereignty, but perhaps more fundamentally in an ur-

${ }^{143}$ Id. at $539-40$.

${ }^{144}$ Id. at $554-55$.

145 Justice Field lodged a scathing dissent previewing his majority opinion in the Chinese Exclusion Case. When Congress refuses to comply with some aspect of a treaty, Field insisted, "it is not for this court or any other court to call in question the validity or wisdom of its action ...." Id. at 562 (Field, J., dissenting). Most of Field's analysis, however, consisted of a long discussion of what he considered the distinct, and distinctly destructive, characteristics of Chinese laborers as a class. "[T]hey had a wonderful capacity to live in narrow quarters without injury to their health," he instructed, "and were generally content with small gains and the simplest fare. They were perfectly satisfied with what would hardly furnish a scanty subsistence to our laborers and artisans. Successful competition with them was, therefore, impossible . . .."Id. at 565-66. Congress enacted the Chinese Exclusion Act, Field observed, in order to halt "the certainty" that "vast hordes would pour in upon us, overrunning our coast and controlling its institutions. A restriction upon their further immigration was felt to be necessary to prevent the degradation of white labor, and to preserve to ourselves the inestimable benefits of our Christian civilization." Id. at 569. Further, because "[t]he consideration for allowing free emigration from China ... . [had] failed," id. at 570, the United States could abrogate the treaty with no breach of faith to China. "If the construction I give works hardship to any persons," Field concluded, "it is for Congress, not this court, to afford the remedy." Id. at $576-77$. 
gent and pervasive discourse of national self-preservation that emerged at the end of the nineteenth century. ${ }^{146}$ For reasons that have little to do with constitutional doctrine, by the mid-1880s a broad consensus had developed among American legislators, judges, and other opinion-makers that unchecked immigration posed something approaching an existential threat to the republic. In response, they transformed the federal immigration power from a form of commercial authority grounded in the Commerce Clause into a power of national self-defense derived from the nation's inherent sovereignty.

Section A analyzes the widely influential writings of immigration critics such as Congressman Henry Cabot Lodge, the economist Richmond Mayo-Smith, and the economist and Superintendent of the U.S. Census Francis A. Walker, as well the congressional debates that these critics directly shaped. These and other prominent figures advanced a forceful-and in the $1880 \mathrm{~s}$ and $1890 \mathrm{~s}$, ubiquitous - critique of European immigration to the United States that interwove concerns about the decline of the "American standard of living," the racial unfitness of unassimilable "new immigrants" from southern and eastern Europe, and the nation's diminished capacity to "digest" large numbers of new arrivals. Section B demonstrates that the terms of this critique closely paralleled the construction of Chinese immigrants in the inaugural plenary power cases. Situating the Chinese Exclusion Case and the virulent anti-Chinese rhetoric that saturated the Court's opinion in the context of this broader critique of immigration reveals that both the cultural and legal origins of modern immigration exceptionalism lie

${ }^{146}$ This argument may be understood to imply that the founding rationale for immigration exceptionalism - the invocation of a national right of self-preservation against an existential threat of alien origin - was unprecedented in the history of American immigration lawmaking. This implication of novelty raises the question of whether the infamous Alien Act of 1798, which authorized the President to remove any alien he judged "dangerous to the peace and safety of the United States," Alien Act, ch. 58, 1 Stat. 570, 571 (1798), may have furnished an early model for the plenary power doctrine. Although some of the arguments advanced in support of the Alien Act foreshadowed the national security rationale a century later, there is little basis to conclude that the Act itself served in any meaningful way as precedent or inspiration for the plenary power doctrine. First, although some of the Act's supporters justified the measure on the basis of necessity, or "self-preservation," the claim that Congress possessed an inherent power to expel aliens did not figure significantly in the debates. Instead, supporters were determined to derive congressional authority from the enumerated clauses, including the Necessary and Proper, Commerce, Migration, General Welfare, Common Defense, and Republican Government Clauses. Second, and most importantly, the Alien Act was adopted during a period of extraordinary hostility toward France (including the severing of diplomatic relations between the countries as well as actual naval combat) known as the "quasi-war," with the purpose of expelling French agents present in the United States. Moreover, it was allowed to expire just two years later, in 1800 , without a judicial resolution of its constitutionality, which was vigorously disputed at the time and the subject of much doubt throughout the nineteenth century. See generally Cleveland, supra note 16, at 87-98. Indeed, even Justice Field, the leading early expositor of the plenary power doctrine, observed in 1893 that the Alien Act had "ever since been the subject of universal condemnation." At no time between 1798 and the enactment of the Immigration Act of 1891, Field declared, "has any public man had the boldness to advocate the deportation of friendly aliens in time of peace." Fong Yue Ting v. United States, 149 U.S. 698, 750 (1893) (Field, J., dissenting). 
in a highly contingent, historically novel association between foreign pauper labor and foreign aggression that, for contemporaries, warranted categorically defining all laws touching on immigration as matters of national selfpreservation.

\section{A. Immigration as Foreign Aggression}

Modern immigration exceptionalism originated in a fundamental antagonism between the nation's cherished values of free labor and republican government and the unprecedented social and economic dislocations wrought by the industrialization of the northern economy. For nearly a century following the nation's founding, both immigration policy and the legal authority to regulate immigration were directly shaped by Americans' prevailing political-economic worldview, which we might call free labor republicanism. As we saw in Part I.A, the United States' relative liberality with respect to immigration, as well as the reservation of most immigration regulation to the states, rested on a broad confidence that an open continent, easy access to land, and exposure to republican political values and institutions would assimilate all comers. In the decades following the Civil War, that confidence was severely eroded.

At the center of free labor republicanism was a model of male citizenship that located the capacity for civic virtue and disinterested political participation in the vaunted idea of personal "independence." In the early republican period, such independence depended on a man's ownership of real property and control over his family's livelihood. ${ }^{147}$ By the postbellum era, however, for the first time in the nation's history a majority of male workers labored for a wage, ${ }^{148}$ as industrialization transformed a citizenry composed largely of self-employed farmers and craftsmen into a population of wage earners. This wholesale reconstruction of the nation's labor system reverberated well beyond the economic sphere, spurring a profound reorganization of Americans' residential geography, social relations, and family life. Most importantly for present purposes, it meant that free labor republicanism, and the meaning of personal independence in particular, would either adapt or fade into history.

Under traditional free labor republicanism, wage labor carried powerful connotations of dependency and subordination. In relinquishing the economic independence associated with property ownership and self-employment, hirelings were understood to have ceded their personal autonomy and

147 See Gordon Wood, The Radicalism of the American Revolution 178 (1991); Ruth H. Bloch, The Gendered Meanings of Virtue in Revolutionary America, 13 Signs 37, 5455 (1987).

148 David Montgomery, Beyond Equality: Labor and the Radical Republicans, $1862-1872$, at $28-30$ (1967). 
political agency to the will of their employers. ${ }^{149}$ Whether a permanent class of wage laborers was compatible with virtuous, independent republican citizenship thus became the paramount ideological problem of the years following the Civil War. In the era of wage labor, would property ownership and self-employment remain an essential component of personal independence? Or might worker-citizens also establish their self-ownership-their independence-through the sale of their labor? By the $1870 \mathrm{~s}$, the latter view was ascendant, as congressional Republicans and political intellectuals in the North and South alike agreed that a man's capacity to alienate his labor for a price manifested his independence, rather than a form of feminizing dependency. ${ }^{150}$

By identifying a worker's capacity to sell his labor as an ideological cornerstone of economic and political independence, the postbellum consensus staked the future of free labor republicanism on the moral integrity of the wage contract. The quality of American citizenship and, ultimately, the very future of the republic, appeared to lie in the balance.

$$
* * *
$$

The national debate over the inclusion of millions of foreign wage laborers within the American polity thus served as a referendum on the broader question of whether an economy premised on liberal economic rela-

${ }^{149}$ Lawrence B. Glickman, A Living Wage: American Workers and the Making of Consumer Culture 22-24 (1997); Montgomery, supra note 148, at 30-33; Daniel T. Rodgers, THE WORK ETHIC IN INDUSTRIAL AMERICA, 1850-1920, at 30-64 (1974); David R. Roediger, The Wages of Whiteness: Race and the Making of the American Working Class 65-87 (1992); Amy Dru Stanley, From Bondage to Contract: Wage Labor, Marriage, and the Market in the Age of Slave Emancipation 9-10 (1998); Robert J. Steinfeld, The Invention of Free Labor: The Employment Relation in English and American Law and Culture, 1350-1870, at 185-87 (1991); William E. Forbath, The Ambiguities of Free Labor: Labor and the Law in the Gilded Age, 1985 WIS. L. REv. 767, 774-75 (1985).

${ }^{150}$ The mid-century conflict over slavery, perhaps more than any other factor, helped to transform the ideological meaning of the wage contract:

Abolitionists extolled the voluntary exchange of one's labor for a wage as the antithesis of slavery. The compulsion inherent in the slave system, they argued, violated the fundamental tenets of both economic morality and human nature, denying the right of man to govern himself, to enjoy bodily integrity, to own property, and to dispose of his labor at market price. Consent became the language of individual freedom, and thus acquired the moral and emotional weight of opposing human bondage. Slave emancipation and the victory of the Union Army further elevated the wage contract as the essence of freedom, individual economic agency, and male independence. The Civil Rights Act of 1866 enshrined this thinking in law, explicitly construing the right to contract for the sale of one's labor as an essential right of citizenship.

Lindsay, supra note 22, at 193. See generally ERIC Foner, ReCONSTRUCTION: AMERICA'S UNFINISHED REVOLUTION, 1863-1877, at 244 (1989); STANLEY, supra note 149, at 1-97; RoNald G. Walters, The Anti-Slavery Appeal: American Abolitionism After 1830 (1976); Forbath, supra note 149, at 785-86. 
tions was compatible with republican citizenship. In the final two decades of the nineteenth century, a growing chorus of Americans voiced their fears that it was not. In the face of increasingly intense wage competition and the appearance of entrenched poverty in the nation's cities, lawmakers, judges, labor spokesmen, and economists named as a leading culprit a phenomenon that they called the "crisis of foreign pauper labor." Unlike "foreign paupers," whose economic dependency had long drawn the attention of state lawmakers and charity administrators, foreign pauper laborers offended through an excess of economic competitiveness. Through their willingness to work for virtually any wage, critics charged, foreign pauper laborers robbed "American" workers of the income necessary to secure for their families a "civilized" standard of living, thereby degrading not only the labor market, but also the ideological foundation of the republic-the personal independence and political virtue of the citizenry. For contemporaries, the economic pathology of foreign pauper labor thus threatened to drive a wedge through the center of late nineteenth-century American political economy, and to render incompatible the citizenly virtues so essential to the political health of the republic, and the economic instrument on which industrial progress depended-namely, the wage contract.

The critique of foreign pauper labor initially took shape both in popular periodicals and in the congressional debates over the Contract Labor Act of 1885, also known as the Foran Act. The Act prohibited the immigration of aliens who had entered into a labor contract prior to departing for the United States. ${ }^{151}$ The greatness and durability of American civilization, the Act's proponents believed, depended above all on the fitness of its working class. The high wages and living standards demanded by American workers both testified to and assured the perpetuation of that fitness. "The American producer is the essential ingredient ... in American civilization," explained Senator Henry Blair, one of the bill's leading congressional advocates. He is an "American civilizer [who] has attained a position where he has a certain amount of compensation ... allotted to him in the distribution of that which he produces ...."152 Ohio Congressman Martin Foran, the bill's sponsor in the House of Representatives, similarly emphasized that high wages were an essential condition of fit citizenship. "It may be laid down as a general proposition that can not be controverted, that the rate of wages determines the social, moral, and intellectual status of a people," he explained. "Low wages mean cheap men, ignorant, degraded, dangerous citizens. . . . Cheapen labor and you destroy the incentives that spur men to effort and improvement. Low wages signify debasement, ignorance, degradation, bru-

151 The Foran Act made it unlawful "to prepay the transportation, or in any way assist or encourage the importation or migration of any alien ... under contract or agreement ... made previous to the importation or migration of such alien . . . to perform labor or service of any kind ...." Contract Labor Act of 1885, chs. 161-64, 23 Stat. 332 (repealed 1952).

15216 Cong. REC. 1,626 (1885). 
tality. High wages signify intelligence, ingenuity, invention, and a higher order of manhood."'153

By placing a premium on a respectable standard of living, critics of foreign pauper labor helped to reconcile the emergence in the United States of a permanent wage earning class with the venerated republican ideal of virtuous citizenship. In so doing, they elaborated a historically novel political economy of American citizenship, adapted specifically to a modern industrial system in which labor was fast becoming the norm rather than a disreputable exception. Senator Orville Platt, a Connecticut Republican, made explicit the vital nexus between high wages and the preservation of republican citizenship:

[Y]ou must add to virtue and intelligence the prosperity of the citizen, if you expect the Republic to endure ... . [T]o lower the standard of wages below fair remuneration is . . . vicious and destructive of republican institutions. . . U Up to this time those who have been willing to labor in this country under our system of free labor have been able to comfortably clothe themselves and [their] families; so that they could properly educate their children; so that by thrift and prudence ... . [they] could . . . secure a little home; attach themselves to the soil, and thus become conservative, patriotic citizens of the country.... [W] shall have but half won the fight against slave labor and in favor of free labor in this country if ... labor shall [not] be free and independent, and . . . receive fair, even generous, compensation. ${ }^{154}$

Under the emergent model, virtuous citizenship would derive not only from property ownership and self-employment, but also from the receipt of a wage sufficient to afford a worker and his family a comfortable material existence and a measure of leisure.

Determined to preserve the "civilization" of the American wage-earning class, a broad cross-section of policymakers, economists, and others directed unprecedented attention to immigrant laborers' "habits, customs, [and] modes of living."155 Members of Congress zealously reported immigrants' inability to appreciate the creature comforts, often singling out the consumption habits of "new" immigrants from southern and eastern Europe for special condemnation. Congressman Foran cited accounts of Hungarian laborers "subsisting upon what an American laborer could not eat-such as mules, hogs, \&c. [sic], which have been killed or died with cholera and other diseases." 156 "[T] he habits, morals, and modes of living of the Italians [are] of the same general character," 157 he reported. Terence

\footnotetext{
${ }^{153} 15$ Cong. ReC. 5,351 (1884).

15416 CONG. REC. 1,781 (1885).

15515 CoNG. ReC. 5,349 (1884).

${ }^{156} I d$. at 5,350

${ }^{157}$ Id.
} 
Powderly, the leader of the powerful Knights of Labor and the future United States Commissioner General of Immigration, agreed that new immigrants' uncivilized living standards rendered them unfit for both the American market in free labor and for American citizenship. "We have Hungarians at work," Powderly insisted, "who are no more fit to live in this country than a hog is fit to grace a parlor." 158 Foreign pauper laborers' degrading influence was due not to their poverty per se, but rather to their failure to aspire to a civilized standard of living. Francis Amasa Walker, the era's preeminent political economist and the future Chief of the United States Census Bureau, deplored the "foreigner, making his way into the little village, bringing . . . not only a vastly lower standard of living, but too often an actual present incapacity to even understand the refinements of life and thought in the community in which he sought a home."159

The Supreme Court endorsed this assessment when it was asked to clarify the class of immigrant laborers excluded by the Contract Labor Act. The Act's purpose, explained a unanimous Court in Holy Trinity Church v. United States, was to "raise the standard of foreign immigrants, and to discountenance the immigration of those who had not sufficient means in their own hands ... to pay their passage." 160 The Court quoted directly from the House committee report on the Act:

This class of immigrants care[s] nothing about our institutions, and in many instances [has] never heard of them; they are men whose passage is paid by the importers. .. . [T] [ hey are ignorant of our social condition, and that they may remain so they are isolated and prevented from coming into contact with Americans. They are generally from the lowest social stratum, and live upon the coarsest food and in hovels of a character before unknown to American workmen. They, as a rule, do not become citizens, and are certainly not a desirable acquisition to the body politic. The inevitable tendency of their presence among us is to degrade American labor, and reduce it to the level of imported pauper labor. ${ }^{161}$

In the Court's estimation, foreign pauper laborers' degraded standards of living held the "inevitable tendency" of poisoning the independence, self-respect, and political virtue of the national citizenry. In a social and political context in which fitness for free labor was virtually coterminous with fitness for republican citizenship, immigrants' low standards of civilization weighed heavily against their political inclusion.

\footnotetext{
${ }^{158} \mathrm{Id}$. at 5,356 .

${ }^{159}$ Francis A. Walker, Immigration and Degradation, 11 Forum 634, 641 (1891).

160143 U.S. 457,464 (1892).

${ }^{161}$ Id. (quoting 15 Cong. ReC. 5,359 (1884)).
} 
Policymakers and other observers routinely rendered their critique of foreign pauper labor in the increasingly resonant language of heredity and race. The racial inheritance of the most recent, and increasingly visible, addition to the American laboring class-the "new" European immigrantswas often singled out for special condemnation. As Walker explained, the defective classes were "increasingly drawn from the nations of southern and eastern Europe-peoples which have got no great good for themselves out of the race wars of centuries, [and have] . . . remained hopelessly upon the lowest plane of industrial life."162 Massachusetts Republican Henry Cabot Lodge, perhaps the leading congressional advocate of immigration restriction, emphasized that the invasion of foreign laborers was also an invasion of foreign races. "We have now before us race problems which are sufficient to tax to the utmost the fortunate conditions with which nature has blessed us," 163 he explained in 1891. The changing source of European immigration was vital. "The immigration of people of those races which contributed to the settlement and development of the United States is declining in comparison with that of races far removed in thought and speech and blood from the men who have made this country what it is."164

Policymakers drew extensively on images of national invasion and infestation to illustrate the unprecedented vulnerability of the American citizenry. As Michigan Republican Byron Cutcheon declared, foreign pauper laborers were

the Goths and Vandals of the modern era. They come only to lay waste, to degrade, and to destroy. They bring with them ignorance, degraded morals, a low standard of civilization, and no motive of intended American citizenship. Like the vast flights of grasshoppers and locusts, . . . they sweep down upon our fields of labor to devour and strip from us the benefit of our customs and the laws protecting American labor, and then take their flight again back to the breeding places from which they came. ${ }^{165}$

Cutcheon's torrent of metaphors, like the statements of so many of his contemporaries, constructed a citizenry in perpetual jeopardy of violation. Republican Senator Lot Morrill made explicit the hereditary dimension of that vulnerability. The nation was being overrun by immigrants "more dangerous to the individuality and deep-seated stamina of the American people, and more worthy of rigid quarantine, then even the most leprous diseases," he declared. ${ }^{166}$ Morrill was referring specifically "to those whose inherent deficiencies and iniquities are thoroughbred, and who are [as] incapable of

162 Walker, supra note 159 , at 644 .

16322 Cong. REC. 2,956 (1891).

164 ld.

16515 Cong. Rec. 5,369 (1884). Morrill).

${ }^{160}$ W.M.F. Round, Immigration and Crime, 8 Forum 428, 428 (1889) (quoting Senator 
evolution, whether in this generation or the next, as is the leopard to change his spots." 167

Between the mid-1880s and the early 1890 s, popular and social scientific periodicals echoed congressional pronouncements that, in the absence of the requisite economic conditions and racial material, simply exposing immigrants to American values and institutions accomplished little as a force of assimilation. The nation appeared to be leaving behind the Jeffersonian and Lincolnian republic in which property ownership and independent labor were essential prerequisites for virtuous citizenship, and entering into a new and unfamiliar world. As Lodge wrote in an 1891 issue of the prestigious North American Review, the United States "no longer [has] endless tracts of fertile land crying for settlement. ... [T] The conditions have changed utterly from the days when the supply of vacant land was indefinite, the demand for labor almost unbounded, and the supply of people very limited." 168 To the dismay of Lodge and many of his contemporaries, the historical pillars of the exceptional republic had ceased to exist, as a host of social crises afflicting European cities-mass poverty, class conflict, radicalism, and political instability - had appeared on the horizon. For Lodge, in fact, that time had already arrived. "In many parts of the country," he concluded, "the struggle for existence in the large cities has become as fierce as in the old world."169

At the heart of this pessimism lay a profound anxiety that the industrial transformation of labor-the displacement of the independent, agrarian producer by the industrial hireling - had rendered the republican ideal of virtuous independent citizenship a hollow anachronism. The belief that "the earth is the great disinfectant," explained Mayo-Smith, "and that all we need do is to get these depraved dregs of European civilization on to the land in order to reform them-it is in this early civilization that this saying is true."170 "As long as there was no danger of the labor market becoming overstocked," agreed a young Theodore Roosevelt in 1888, "we were able with safety to trust to our extraordinary powers of assimilation to turn the immigrants or their children, sooner or later, into American citizens, with the same feelings, prejudices[,] and habits of thought as the rest of us." 171 "The growth of a proletariat," however, "would surely in the end bring about the overthrow of our whole system." 172

The critique of European immigration described in this Section both reflected and helped to manifest the emergence of a novel, distinctively modern understanding of the American polity. The quality of the citizenry would no longer be guaranteed by the assimilative influences of free labor

\footnotetext{
${ }^{167} \mathrm{Id}$.

${ }^{168}$ Henry Cabot Lodge, The Restriction of Immigration, 152 N. AM. REv. 27, 34 (1891).

${ }^{169} \mathrm{ld}$.

${ }^{170}$ Richmond Mayo-Smith, Control of Immigration, 3 PoL. Scl. Q. 409, 413 (1888).

${ }_{171}$ Theodore Roosevelt, The Immigration Problem, 7 HARv. MoNTHLY 85, 85-86 (1888).

${ }^{172}$ Id. at $86-87$.
} 
and republican political institutions. Rather, it would be defined in opposition to and defended against the forces of invasion: the uncivilized, racially inferior, citizenship-decaying material of unfit immigrant laborers. As we will see in the next Section, it is precisely this deep sense of vulnerability at the hands of a foreign menace that shaped the modern immigration power.

\section{B. "The National Right of Self-Preservation"}

This Section analyzes the legal advent of the modern era of immigration exceptionalism. When the Court announced in the Chinese Exclusion Case and subsequent decisions that Congress's authority to exclude aliens was inherent in the nation's sovereignty, essential to its self-preservation, and "conclusive upon the judiciary," it yoked the immigration power to Congress's undisputed authority over fundamental matters of national "peace and security," and the conduct of war. ${ }^{173}$ Further, with the Immigration Act of 1891, and in various amendments to the Chinese Exclusion Act, Congress played an aggressive, if largely unacknowledged, role in claiming for itself an immigration authority that operated largely beyond the reach of judicial review.

\section{The Chinese Exclusion Case}

The Supreme Court's 1889 decision in Chae Chan Ping v. United States, ${ }^{174}$ titled the Chinese Exclusion Case by its author, Justice Stephen Field, shifted the source of congressional authority to regulate immigration from the Commerce Clause, where it had resided for more than half a century, to the ill-defined, though apparently extra-constitutional, concept of national sovereignty. Writing for a unanimous Court, Justice Field translated the discourse of national emergency discussed above into a potent and durable rationale for immigration exceptionalism. He forged the immigration power into an instrument of national self-defense, to be deployed against invading armies of politically unassimilable, economically degraded, and racially suspect foreigners. Though Chinese laborers were in fact subjects of a "most favored nation" under the Burlingame and 1880 treaties, Field recast them as enemy aliens.

Chae Chan Ping, a Chinese laborer, had resided in San Francisco from 1875 until June 2, 1887, when he departed for China. He brought with him a certificate issued pursuant to the 1882 Act and 1884 amendments, entitling him to return to the United States. ${ }^{175}$ On October 1, 1888, Congress again amended the Chinese Exclusion Act, now prohibiting any Chinese laborer who had resided in the United States and subsequently departed from ever

\footnotetext{
${ }^{173}$ See infra note 179.

174130 U.S. 581 (1889).

${ }^{175}$ Id. at 582 .
} 
returning. The Act thus voided every certificate of reentry issued under the 1882 and 1884 Acts, and prohibited the landing of any Chinese laborer claiming admission on the basis of such a certificate. ${ }^{176}$ Eight days later, Chae Chan Ping arrived in the port of San Francisco. When he presented his certificate, the collector denied him entry on the ground that "the certificate had been annulled and his right to land abrogated," 177 and detained him on board the passenger ship. The case came before the Court on a writ of habeas corpus. ${ }^{178}$

Justice Field's opinion upholding Chae Chan Ping's exclusion resonated profoundly with the contemporaneous assessments of European immigration discussed above. ${ }^{179}$ Like the critiques levied by Lodge, Mayo-Smith, and others against hordes of invading "foreign pauper laborers," Field's opinion was rooted in a historical narrative of anticipated economic value and republican ideals dashed by uncivilized standards of living, degradation of the wage contract, and, ultimately, racial difference. The Burlingame Treaty operated in the opinion as the benchmark against which the nation's actual subsequent experience with Chinese immigration should be measured. ${ }^{180}$ In Field's view, the past twenty years of Chinese immigration had made a mockery of the liberal optimism embodied in the Treaty and defied earlier expectations of its economic benefits. "The belief was general, and confidently expressed, that great benefits would follow to the world generally and especially to the United States," 181 he explained. On the basis of such ex-

${ }^{176}$ Scott Act of 1888, ch. 1064, § 2, 25 Stat. 504 (repealed 1943).

177 The Chinese Exclusion Case, 130 U.S. at 582.

${ }^{178}$ Chae Chan Ping acknowledged the nation's "inherent right [as] a sovereign power" to prohibit the entry of aliens into its territory - an authority derived, he noted, from Congress's foreign commerce power-but insisted that such a right did not authorize the United States to revoke his "vested right to return." Id. at 585. The source of that right, he argued, was twofold. First, because he had come to the United States under the Burlingame Treaty, which recognized the "inherent and inalienable right of man to change his home and allegiance," Congress could not oblige him "to surrender [his] residence . . . acquired under such invitations and guaranties." Id. at 586. The only plausible basis historically for "compelling an alien friend to leave the country," he argued, grimly foreshadowing Justice Field's opinion, "was that it was a measure in preparation for anticipated war, and, therefore, an exercise of the war power." Id. Second, Chae Chan Ping argued that the United States was contractually bound to readmit him. The certificate provisions in the 1882 and 1884 Acts "contained an offer on the part of the United States to every Chinese laborer then in this country, if he should leave the country and comply with the conditions therein . . . to permit him to return," he maintained. Id. at 587.

${ }^{179}$ The holding rested on two closely related points of law. First, the provision of the 1880 treaty stating that Chinese laborers currently in the United States "shall be allowed to go and come of their own free will" did not endow such laborers with a judicially enforceable right. Rather, the authority to judge the wisdom or propriety of disregarding a treaty obligation, the Court explained, "has not been confided to the judiciary, ... but to the executive and legislative departments of the government ...." Id. at 602. Second, Congress possessed the authority to prohibit Chinese laborers who departed the United States from returning. Such authority was incident to the United States' sovereignty as an independent nation, the Court declared, and therefore "conclusive upon the judiciary." Id. at 606.

${ }^{180} \mathrm{Id}$. at 592.

${ }^{181} \mathrm{Id}$. 
pectations, he suggested, the United States had recognized the "inherent and inalienable right of man to change his home and allegiance, and also the mutual advantage of the free migration and emigration ... from the one country to the other." 182

Even before the ink on the Treaty had dried, however, "events were transpiring on the Pacific Coast which soon dissipated the anticipations indulged as to the benefits to follow the immigration of Chinese to this country." 183 The Chinese laborers who arrived on the Pacific coast after the discovery of gold in California in 1848 "proved to be exceedingly useful,"184 Field explained, but as their numbers increased they came into competition with American workers. ${ }^{185}$ "[C]ontent with the simplest fare, such as would not suffice for our laborers and artisans," and without families to support, the labor market competition "between them and our people was . . . altogether in their favor." 186 "The differences of race added greatly to the difficulties of the situation," 187 Field continued. Notwithstanding the Treaty's "favorable provisions," Chinese immigrants "remained strangers in the land, residing apart by themselves, and adhering to the customs and usages of their own country. It seemed impossible for them to assimilate with our people, or to make any changes in their habits or modes of living."188 As their numbers grew, Field reported, the "people of the coast saw . . . great danger that at no distant day that portion of our country would be overrun by them, unless prompt action was taken to restrict their immigration." 189

In response, the 1878 California Constitutional Convention appealed to Congress that the immigration of Chinese laborers "was in numbers approaching the character of an Oriental invasion, and was a menace to our civilization . . . that they retained the habits and customs of their own country, and in fact constituted a Chinese settlement within the state, without any interest in our country or its institutions." 190 So urgent was the cause, Field explained, that Congress felt "impelled" to send a commission to China to renegotiate the terms of the Burlingame Treaty. ${ }^{191}$ Those negotiations produced the Treaty of 1880 , permitting the United States to limit or suspend Chinese immigration, thus clearing the way for the Chinese Exclusion Act of 1882. That Act suspended the immigration of Chinese laborers for a period of ten years and conditioned the return of departing laborers on their possession of a certificate of reentry. The early enforcement of the Act, Field explained, "was attended with great embarrassment, from the suspicious nature

$182 \mathrm{Id}$. at 592 (quoting the Burlingame Treaty, supra note 37 , art. 5 ).
$183 \mathrm{Id}$. at 593 .
$184 \mathrm{Id}$. at 594 .
$185 \mathrm{Id}$.
${ }^{186} \mathrm{Id}$. at 595.
$187 \mathrm{Id}$.
$188 \mathrm{Id}$.
$189 \mathrm{Id}$.
$190 \mathrm{Id}$. at $595-96$.
$191 \mathrm{Id}$. at 596. 
... of the testimony offered to establish the residence of the parties." 192 Congress responded with the 1884 amendments, making the certificate the only permissible evidence of an immigrant's right of reentry. ${ }^{193}$ However, the "same difficulties and embarrassments continued" after the Court in Chew Heong exempted from the certificate requirement laborers who had departed before the 1882 Act and returned after the 1884 amendments. Only then, Field concluded, after six years of rampant, fraudulent evasion of the Act, did Congress void all previously issued certificates of reentry. ${ }^{194}$

After spending twelve pages narrating this history, Justice Field disposed of the basic legal issue_-Chae Chan Ping's claim of a treaty-based right to reenter-in a single, apparently legally uncontroversial paragraph. Field conceded that the 1888 Act directly contravened the 1868 and 1880 treaties, but maintained that this did not invalidate the Act. Because the Constitution declares both treaties and acts of Congress "to be the supreme law of the land, and [gives] no paramount authority ... to one over the other," he reasoned, "the last expression of the sovereign will must control." 195 Indeed, that analysis reflected the Court's long-standing position, which it had reaffirmed only the previous term. ${ }^{196}$

If Field could thus summarily dispose of Chae Chan Ping's legal argument, why, then, did he go to such lengths to instruct his audience on the history of Sino-American treaty relations, the degradation of American labor, Chinese racial difference, the failure to assimilate, and the chronic evasions of the exclusion laws? After all, none of these facts appears relevant, let alone necessary, to his legal conclusion. The answer, I propose, is that the historical narrative provides the essential foundation for the broader ambition of Field's opinion-to reconstruct the federal immigration power as an instrument of national self-defense, grounded in United States' sovereignty as an independent nation and reserved for the political departments of government.

Field began that reconstruction by defining the nation's sovereignty in terms of Congress's enumerated powers with respect to "foreign countries and their subjects or citizens."197 "The powers to declare war, make treaties, suppress insurrection, repel invasion, regulate foreign commerce, secure republican governments to the states, and admit subjects of other nations to citizenship, are all sovereign powers," 198 he explained. Although at first blush the inclusion of foreign commerce on a list otherwise comprised of diplomatic- and security-related powers is somewhat striking, Field hastened

\footnotetext{
${ }^{192} I d$. at 598.

${ }^{193} \mathrm{Id}$.

${ }^{194}$ Id. at 599.

${ }^{195}$ Id. at 600 .

${ }^{196}$ See Whitney v. Robertson, 124 U.S. 190, 194 (1888) (holding that when a treaty and federal statute conflict, the more recent one controls).

${ }^{197}$ The Chinese Exclusion Case, 130 U.S. at 604.

${ }^{198}$ Id.
} 
to add that all such sovereign powers were "restricted in their exercise" not only by "considerations of public policy and justice," but "by the Constitution itself." 199 Read in light of Henderson, Chy Lung, the Head Money Cases, and Chew Heong, this passage could plausibly be interpreted to crystallize what I have argued was the Court's established understanding of the federal immigration power: an authority derived from Congress's commerce power, encompassing the foreign-relations dimension of immigration, and subject to constitutional constraints.

Upon thus reaffirming the essentially national nature of the United States' sovereignty over immigration, Field pivoted sharply. Building on the historical groundwork laid earlier in the opinion, he wrote:

To preserve its independence, and give security against foreign aggression and encroachment, is the highest duty of every nation, and to attain these ends nearly all other considerations are to be subordinated. It matters not in what form such aggression and encroachment come, whether from the foreign nation acting in its national character, or from vast hordes of its people crowding in upon us . . . 200

At issue in the case, Field suggested, was not merely congressional authority to exclude foreigners; that Congress possessed such authority had been well established at least since the Court decided the Passenger Cases forty years earlier. The passage constructs Chinese laborers as agents of foreign aggression. This is remarkable for at least two reasons. First, it defies the basic rule of international law that "aliens are responsible only for . . . offenses in which their nation bears a part," in which case they become "enemy aliens."201 Not even Field suggests, however, that Chinese laborers were literally agents of China. Second, even if Chinese laborers had been acting as agents of their home government, at the time the case was decided the United States enjoyed cordial relations with China, at least formally, and the 1880 treaty had guaranteed to Chinese laborers then residing in the United States "all the rights, privileges, immunities and exemptions which are accorded to the citizens . . . of the most favored nation." 202 Under the law of nations, Chinese laborers were therefore "alien friends," however undesirable they may have been to members of Congress or the justices of the Supreme Court.

After thus collapsing key distinctions between, first, China "acting in its national character" and the "vast hordes" of Chinese subjects, and, sec-

\footnotetext{
199 Id.

${ }^{200} I d$. at 606.

${ }^{201}$ The Passenger Cases, 48 U.S. 283, 510 (1849) (Daniel, J., dissenting); see supra text accompanying notes $97-98$.

${ }^{202}$ Immigration Treaty of 1880 , supra note 135 , art I.
} 
ond, alien friends and alien enemies, Field turned to the nature of Congress's power of exclusion:

If . . the government of the United States, through its legislative department, considers the presence of foreigners of a different race in this country, who will not assimilate with us, to be dangerous to its peace and security, their exclusion is not to be stayed because at the time there are no actual hostilities with the nation of which the foreigners are subjects. The existence of war would render the necessity of the proceeding only more obvious and pressing. The same necessity . . . may arise when war does not exist, and the same authority [applies]. . . . In both cases its determination is conclusive upon the judiciary. ${ }^{203}$

As we saw in Part I, beginning with Miln in 1837 and continuing up through Chew Heong in 1884, the authority to regulate immigration and to exclude specific classes of immigrants derived from Congress's constitutionally enumerated power to regulate commerce. That authority accommodated the acknowledged foreign-affairs dimension of federal immigration policy, and it was subject to meaningful judicially enforceable constraints. The above passage represents a stark rejection of that framework. Congress's authority to exclude Chinese laborers derived not from its commerce power, but was "an incident of sovereignty belonging to the government of the United States."204 Perhaps most remarkably, that authority was now identical to Congress's power to conduct war. As an act undertaken to repel foreign aggression, Congress's decision to void Chae Chan Ping's certificate of reentry was "conclusive upon the judiciary."205

Having thus reconstructed the federal immigration power, Field retroactively revised the Court's rationale in previous decisions upholding Congress's authority to exclude undesirable classes of Europeans. He wrote:

The exclusion of paupers, criminals and persons afflicted with incurable diseases, for which statutes have been passed, is only an application of the same power to particular classes of persons, whose presence is deemed injurious or a source of danger to the country. ... [T] here has never been any question as to the power to exclude them. The power is constantly exercised; its existence is involved in the right of self-preservation. ${ }^{206}$

Just five years earlier in the Head Money Cases, the Court had reaffirmed that a federal statute "designed to mitigate the evils inherent in the business of bringing foreigners to this country" lay squarely within Congress's com-

${ }^{203}$ The Chinese Exclusion Case, 130 U.S. 581, 606 (1889).

${ }^{204} \mathrm{Id}$. at 609

${ }^{205}$ Id. Field added that "[i]f there be any just ground of complaint on the part of China, it must be made to the political department of our government . ..." Id.

${ }^{206}$ Id. at 608 . 
merce power ${ }^{207}$ In the Chinese Exclusion Case, mitigating those evils became a matter of national self-preservation, as immigrants' very foreignness displaced the commercial character of the immigration system as an irreducible premise of the immigration power.

\section{The Triumph of Plenary Power: Legislative and Judicial Consolidation}

Any suspicion that the reconstructed federal immigration power announced in the Chinese Exclusion Case was an anomaly, borne of anti-Chinese racism or the singular features of the Chinese Exclusion Act, evaporated almost immediately. In 1891, two interrelated developmentsthe first legislative, the second judicial_projected Justice Field's framework beyond Chinese exclusion and onto the nation's general immigration laws. First, Congress enacted the Immigration Act of $1891,{ }^{208}$ which foreclosed access to the federal courts for aliens denied entry by federal immigration inspectors. Second, in upholding this jurisdiction stripping provision, the Supreme Court confirmed that, notwithstanding Justice Field's earlier focus on the special difficulties associated with Chinese immigration, neither the outcome of the Chinese Exclusion Case nor the national security rationale were contingent on the particularities of the Chinese menace. ${ }^{209}$ Congress's authority over all foreign immigration was inherent in the nation's sovereignty, calculated to defend the nation against foreign aggression, and conclusive upon the judicial department. Two years later, the Court extended this principle to cover not only the exclusion of foreigners, but also the expulsion of resident aliens. ${ }^{210}$

The Immigration Act of 1891 modified the existing immigration framework in three important respects. First, it supplemented the previous list of excludable classes with "persons likely to become a public charge," among other additions. ${ }^{211}$ Second, it assigned exclusive authority to administer the immigration laws, including the actual inspection of immigrants, to a national Superintendent of Immigration lodged within the U.S. Treasury Department. ${ }^{212}$ Third, and most important for the trajectory of the federal immigration power, the Act made final the decisions of inspection officers 125-127.

207 The Head Money Cases, 112 U.S. 580, 595 (1884); see supra text accompanying notes

${ }^{208}$ Immigration Act of 1891, ch. 551, 26 Stat. 1084.

${ }^{209}$ See Nishimura Ekiu v. United States, 142 U.S. 651, 663-64 (1891).

${ }^{210}$ See Fong Yue Ting v. United States, 149 U.S. 698, 731-32 (1893).

211 Immigration Act of 1891 , ch. 551, $\S 1,26$ Stat. 1084. The Act provided "that the following classes shall be excluded from admission into the United States . . . : All idiots, insane persons, paupers or persons likely to become a public charge, persons suffering from a loathsome or a dangerous contagious disease, persons who have been convicted of a felony or other infamous crime or misdemeanor involving moral turpitude, polygamists, and also any person whose ticket or passage is paid for with the money of another or who is assisted to come ...." Id.

${ }^{212} I d . \S 7$. 
"touching the right of any alien to land," subject to review only by the Superintendent of Immigration and the Secretary of the Treasury. ${ }^{213} \mathrm{Re}$ markably, this provision received no attention during the otherwise rich and extensive legislative debates over the 1891 Act. $^{214}$

In Nishimura Ekiu v. United States, the Court interpreted the 1891 Act to virtually foreclose judicial review of administrative immigration decisions, thus consolidating a foundational element of modern immigration exceptionalism. Nishimura Ekiu, a Japanese woman, arrived in the port of San Francisco on May 7, 1891, just two months after Congress had passed the 1891 Act. The California immigration commissioner, acting under the authority of the Treasury Secretary, prohibited Ekiu from landing and detained her in custody pending her return to Japan. ${ }^{215}$ Later that day, the federal district court in San Francisco issued a writ of habeas corpus. On May 18, the federal inspector for the port of San Francisco, who had been appointed by the Treasury Secretary just four days earlier, intervened in opposition to the writ, claiming that Ekiu was excludable under the 1891 Act as a person "liable to become a public charge," 16 and, further, that his decision to deny admission was not reviewable by the court. The circuit court excluded from the hearing on Ekiu's petition evidence offered in support of her right to land, and held that under the 1891 Act the inspector's decision was final and not subject to judicial review. 217 The Supreme Court affirmed.

Justice Gray's opinion for the Court would do more than any other to establish the basic terms of the federal immigration power for the next century. He declared at the outset:

It is an accepted maxim of international law that every sovereign nation has the power, as inherent in sovereignty, and essential to self-preservation, to forbid the entrance of foreigners within its dominions, or to admit them only in such cases and upon such conditions as it may see fit to prescribe .... In the United States this power is invested in the national government, to which the Constitution has committed the entire control of international relations, in peace as well as in war. ${ }^{218}$

This formulation of the plenary power doctrine became the primary rhetorical and doctrinal touchstone for subsequent immigration cases. First, the passage reaffirmed the Court's conclusion in the Chinese Exclusion Case that Congress's authority to exclude aliens derived from the nation's inherent

${ }^{213} I d . \$ 8$.

${ }^{214}$ SALYER, supra note 15 , at $26-27$.

${ }^{215}$ Nishimura Ekiu v. United States, 142 U.S. 651, 652 (1891). The commissioner apparently determined that Ekiu was excludable under the Immigration Act of 1882, though the Supreme Court's opinion does not note the specific grounds of her exclusion. Id.

${ }^{216} I d$. at 656 .

217 See id.

2181 Sir Robert Phillimore, Commentaries on International Law ch. 10, § 220 (3d ed. 1888); id. at 659 (citing 2 EMer de Vattel, The Law of Nations $\$ \$ 94,100$ (1797)). 
sovereignty under international law. Second, Gray's reference to "self-preservation" invoked Justice Field's national security rationale, and extended that rationale to the regulation of all immigrants, not just Chinese laborers. Third, Gray established that the regulation of all immigration covered by the 1891 Act-that is, all non-Chinese immigration-lay squarely within the domain of foreign relations. This formulation accomplished all of these things, moreover, by way of reviewing a statutory provision the express purpose of which was merely to prevent public economic dependency, and which applied overwhelmingly to European immigrants. It may be tempting to interpret the opinion as simply a rote application of a rule adopted previously in a different, unique context. As Part II.A demonstrated, however, Americans' assessments of Chinese and European immigration bore remarkable similarities. It was the shared terms of their respective critiques that permitted the Court to transpose the national security rationale from the context of Chinese exclusion to all other immigration. ${ }^{219}$

Most importantly, the Court upheld the provision of the 1891 Act foreclosing recourse to the federal courts for aliens judged inadmissible by federal inspectors. Gray reasoned:

It is not within the province of the judiciary to order that foreigners who have never been naturalized, nor acquired any domicile or residence within the United States, nor even been admitted into the country pursuant to law, shall be permitted to enter, in opposition to the constitutional and lawful measures of the legislative and executive branches of the national government. ${ }^{220}$

The decision to deny admission to a would-be immigrant could be, by virtue of her alienage, consigned exclusively to the "political departments" of the government. With respect to aliens, the Court concluded, "the decisions of executive or administrative officers, acting within powers expressly con-

${ }^{219}$ Notwithstanding his invocation of inherent sovereignty, however, Gray did not entirely sever from the Constitution Congress's authority to exclude immigrants. While the passage appeared to claim that the "plenary" nature of that power flowed from the United States" inherent sovereignty as an independent nation, its actual source, as well as its locus of operation within the federal government, remained more ambiguous. The power resided in the national government because the Constitution had vested it there, Gray suggested. The power to exclude aliens "belongs to the political department of the government," he continued, "and may be exercised either through treaties made by the President and Senate, or through statutes enacted by Congress, upon whom the Constitution has conferred power to regulate commerce with foreign nations . . . N Nishimura Ekiu, 142 U.S. at 659. Even as the Court rooted modem immigration exceptionalism in a theory of inherent sovereignty, therefore, it continued to appeal to constitutionally enumerated powers, including the commerce power, as a supplemental source of authority.

${ }^{220} \mathrm{Id}$. at 660 . Justice Gray elaborated: "[T] he final determination of those facts may be intrusted [sic] by Congress to executive officers; and [when] . . . a statute gives a discretionary power to an officer, to be exercised by him upon his own opinion of certain facts, he is made the sole and exclusive judge of the existence of those facts, and no other tribunal, unless expressly authorized by law to do so, is at liberty to re-examine or controvert the sufficiency of the evidence on which he acted." Id. 
ferred by Congress, are due process of law."221 In contrast to the purposeoriented police and commerce rationales that prevailed throughout the nineteenth century, the decision thus staked the source, nature, and scope of the immigration authority on the non-citizenship of the persons against whom it was exercised.

Two years later, in Fong Yue Ting, a sharply divided Court extended the plenary power doctrine from the exclusion of aliens to their deportation. ${ }^{222}$ At issue in the case was a provision of the Geary Act renewing for a second ten-year term the Chinese exclusion policy enacted in 1882. The Act required all Chinese laborers within the United States at the time of its passage to apply within one year for a "certificate of residence."223 Any Chinese laborer who refused to comply would be adjudged to be in the United States unlawfully, and subject to arrest and deportation unless he could establish, first, "that by reason of accident, sickness, or other unavoidable cause, he has been unable to procure his certificate," and, second, "by at least one credible white witness, that he was a resident of the United States at the time of the passage of this act." 224 Chinese immigrants organized a massive campaign of resistance to the certificate program. As a result, when the registration deadline passed on May 5, 1893, only 13,242 Chinese in the United States had registered, leaving an estimated 85,000 in violation of the law and subject to deportation. ${ }^{225}$ Each of the three petitioners alleged that he had been arrested and detained without due process of law, and maintained that the Geary Act's registration requirement was unconstitutional and void. ${ }^{226}$

The Court responded with a sweeping affirmation of Congress's broad authority not only to exclude foreigners, but to expel resident aliens. The majority opinion, again authored by Justice Gray, began by restating the "general principles of public law which lie at the foundation of these cases." 227 Those general principles now consisted entirely of the passage from Nishimura Ekiu discussed above, defining the federal immigration power as one "inherent in sovereignty and essential to self preservation."228 Gray then reprised Justice Field's "repelling foreign aggression" rationale

${ }^{221} I d$.

222149 U.S. 698 (1893).

${ }^{223}$ Id. at 703 .

${ }^{224}$ Act of May 5, 1892, ch. 60, § 6, 27 Stat. 25.

${ }^{225}$ SAL YER, supra note 15 , at 47-48.

${ }^{226}$ Fong Yue Ting, 149 U.S. at 703. Two of the petitioners, Fong Yue Ting and Wong Quan, had refused to register. The third, Lee Joe, had attempted to register but was refused a certificate on the ground that "the witnesses whom he produced to prove that he was entitled to the certificate were persons of the Chinese race and not credible witnesses . . . " Id.

${ }^{227}$ Id. at 704.

${ }^{228}$ Even as the Court insisted that the plenary nature of the United States' authority to exclude and expel aliens flowed from its inherent sovereignty as an independent nation, however, as in Nishimura Ekiu, Gray continued to summon the Constitution. The President and Congress "are vested by the Constitution with the entire control of international relations," he explained. Id. at 711 . The Constitution confers on the President the authority to conduct the nation's diplomatic relations, and makes him the Commander-in-Chief of the army and navy. Likewise, "[t]he Constitution has granted to Congress the power to regulate commerce with 
from the Chinese Exclusion Case. He defined the exclusion and expulsion of aliens as a matter of foreign relations, and war and peace; warned that anything short of an absolute power to exclude and expel could subject the nation to "the control of another power"; and conflated Chinese immigrants with the Chinese nation, and alien friends with alien enemies. ${ }^{229}$ Notably, the Court did not take the position that Congress and the Executive operated outside of the Constitution in their creation and enforcement of the immigration laws, but rather that any assessment of the constitutionality of such laws had been consigned to the political departments. ${ }^{230}$

Justices Field and Brewer lodged lengthy and forceful dissents. ${ }^{231}$ Both objected that the Geary Act's registration requirement imposed punishment without due process of law and that the petitioners were entitled to constitutional protection as persons residing lawfully within the United States. Brewer offered a direct and trenchant critique of the inherent powers doctrine:

This doctrine of powers inherent in sovereignty is one both indefinite and dangerous. Where are the limits to such powers to be found? ... Is it within legislative capacity to declare the limits? If so, then the mere assertion of an inherent power creates it, and despotism exists. May the courts establish the boundaries? Whence do they obtain the authority for this? ... The expulsion of a race may be within the inherent powers of a despotism. ${ }^{232}$

Though Justice Field's objection to the Court's decision hinged formally on the "wide and essential difference" between "legislation for the exclusion of Chinese persons .... and legislation for the deportation of those who have acquired a residence," 233 the author of the Chinese Exclusion Case used most

foreign nations, including . . . the bringing of persons into the ports of the United States . ..." Id. at 712 .

${ }^{229} \mathrm{Id}$. at 705 . Gray likewise revisited Justice Field's historical narrative describing the nation's actual experience with Chinese immigration as a failed referendum on the hopes and ideals embodied in the Burlingame Treaty. "After some years' experience under that treaty," he wrote, "the government of the United States was brought to the opinion that the presence within our territory of large numbers of Chinese laborers, of a distinct race and religion, remaining strangers in the land, residing apart by themselves, tenaciously adhering to the customs and usages of their own country, unfamiliar with our institutions, and apparently incapable of assimilating with our people, might endanger good order, and be injurious to the public interests ...."Id. at 717 .

${ }^{230} \mathrm{Id}$. at 731 ("The question whether, and upon what conditions, these aliens shall be permitted to remain within the United States being one to be determined by the political departments of the government ... the judicial department cannot properly express an opinion upon the wisdom, the policy, or the justice of the measures enacted by Congress in the exercise of the powers confided to it by the Constitution over this subject.").

${ }^{231}$ Chief Justice Fuller dissented as well, though briefly. He sharply distinguished the power to exclude from the power to expel, and argued that the government "cannot, in virtue of any delegated power, or . . . of a supposed inherent sovereignty, arbitrarily deal with persons lawfully within the peace of its dominion." Id. at 762 (Fuller, C.J., dissenting).

${ }^{232}$ Id. at 737 (Brewer, J., dissenting).

${ }^{233}$ Id. at 746 (Field, J., dissenting). 
of his dissent to attack what he viewed as the majority's inappropriate conflation of alien friends with alien enemies. "Aliens from countries at peace with us," he explained, "domiciled within our country by its consent, are entitled to all the guaranties for the protection of their persons and property which are secured to native-born citizens . . .."234 Not since the infamous Alien Act of 1798 , Field chided, "has any public man had the boldness to advocate the deportation of friendly aliens in a time of peace."235

Nishimura Ekiu and Fong Yue Ting barred judicial review not only of substantive immigration policy, but of procedural claims as well. As the Court stated in Nishimura Ekiu, "the decisions of executive or administrative officers, acting within powers expressly conferred by Congress, are due process of law." ${ }^{236}$ A decade later, in The Japanese Immigrant Case, ${ }^{237}$ the Court retreated slightly, creating a narrow opening for procedural review. Notwithstanding the political departments' broad authority to exclude or expel aliens, Justice Harlan reasoned, the Court had never held that administrative officers "may disregard the fundamental principles that inhere in 'due process of law' ...." ${ }^{238}$ An executive officer could not "arbitrarily ... cause an alien ... to be taken into custody and deported without giving him all opportunity to be heard . . ."239 To be sure, the Court's review of the immigrant's (ultimately unsuccessful) procedural claim was stunningly deferential, ${ }^{240}$ and subsequent procedural claims virtually always failed. ${ }^{241} \mathrm{Nev}$ ertheless, The Japanese Immigrant Case did establish a formal doctrinal foothold for procedural due process claims that subsequently provided a doctrinal basis for meaningful, if still highly deferential, judicial review. ${ }^{242}$

${ }^{234} I d$. at 754 .

${ }^{235} \mathrm{Id}$. at 750 .

${ }^{236}$ Nishimura Ekiu v. United States, 142 U.S. 651, 660 (1891); see also Lem Moon Sing v. United States, 158 U.S. 538, 544-46 (1894) (holding that the exclusion order of an executive officer was due process of law).

237 Yamataya v. Fisher (The Japanese Immigrant Case), 189 U.S. 86 (1903).

${ }^{238} \mathrm{Id}$. at 100 .

${ }^{239}$ Id. at 101 .

${ }^{240}$ The petitioner, who had been excluded under the "public charge" provision of the 1891 Act, claimed that she had not been afforded a meaningful opportunity to challenge the decision of the immigration officer. "It is true that she pleads a want of knowledge of our language; that she did not understand the nature and import of the questions propounded to her; that the investigation made was a 'pretended' one; and that she did not, at the time, know that the investigation had reference to her being deported from the country," the Court acknowledged. But "[t]hese considerations cannot justify the intervention of the courts. . . . Whether further investigation should have been ordered was for the officers, charged with the execution of the statutes, to determine. . . . Suffice it to say, it does not appear that appellant was denied an opportunity to be heard. ... If the appellant's want of knowledge of the English language put her at some disadvantage in the investigation conducted by that officer, that was her misfortune, and constitutes no reason, under the acts of Congress, or under any rule of law, for the intervention of the court by habeas corpus." Id. at 101-02.

${ }^{241}$ See, e.g., Oceanic Steam Navigation Co. v. Stranahan, 214 U.S. 320 (1909); United States v. Ju Toy, 198 U.S. 253 (1905); United States v. Sing Tuck, 194 U.S. 161 (1904).

${ }^{242}$ See Motomura, supra note 15 , at 1652 (describing a due process revolution in immigration law culminating in the Court's 1982 decision in Landon v. Plasencia, 459 U.S. 21,33 


\section{Conclusion: Toward an Unexceptional Immigration Power}

The analysis set forth above functions as a historical critique of the contemporary immigration power in two respects. First, by drawing attention to the unique contingencies that surrounded the Court's adoption of the national security rationale for broad judicial deference, my analysis helps to historicize, or denaturalize, what remains a fundamental premise of immigration exceptionalism today. As I argued in Part II, it was the historically novel association in the late nineteenth century between foreign pauper labor and foreign aggression that appeared to warrant categorically defining all laws touching on immigration as matters of national security. In response, the Supreme Court transformed the federal immigration power from a species of commercial authority grounded in the Commerce Clause into a potent instrument of national self-defense, to be deployed against foreign aggression. The power continues to operate today as an extension of Congress's power to conduct foreign affairs and preserve national security, ${ }^{243}$ a power buffered against judicially enforceable constitutional constraints. ${ }^{244}$ Of

(1982), in which the Court held that a returning alien was entitled to due process in her exclusion hearing).

${ }^{243}$ As the Supreme Court recently declared in Demore v. Hyung Joon Kim, quoted at the beginning of this Article, judicial deference toward congressional-and, by delegation, executive-power over immigration is warranted because "any policy toward aliens is vitally and intricately interwoven with contemporaneous policies in regard to the conduct of foreign relations, the war power, and the maintenance of a republican form of government." Demore v. Hyung Joon Kim, 538 U.S. 510, 522 (2003). The federal government, in particular, continues to invoke the national security rationale in its briefs to the Court. See, e.g., Brief of Respondent at 25, Nguyen v. INS, 533 U.S. 53 (2001) (No. 99-2071) (urging the Court to uphold against an equal protection challenge a provision of the Immigration and Nationality Act making children of unmarried citizen mothers born abroad U.S. citizens at birth, but requiring children of unmarried citizen fathers born abroad to take various affirmative steps to gain eligibility for U.S. citizenship, on the grounds that deference to the political branches "affords Congress the practical latitude it needs to fulfill its responsibilities for national security, foreign affairs, and nation-building").

${ }^{244}$ While due process norms today provide the modern deportation regime with a "flexible touchstone of fundamental fairness," writes Daniel Kanstroom, the plenary power doctrine has "impeded the development of coherent substantive principles of constitutional deportation law." Kanstroom, supra note 13, at 17. Two cases argued in 1976-Fiallo v. Bell, 430 U.S. 787 (1977), and Mathews v. Diaz, 426 U.S. 67 (1976) - serve as the primary doctrinal touchstones of the contemporary immigration power. As the Fiallo Court observed, "[o]ur cases 'have long recognized the power to expel or exclude aliens as a fundamental sovereign attribute exercised by the Government's political departments largely immune from judicial control." "Fiallo, 430 U.S. at 792 (quoting Shaughnessy v. United States ex rel. Mezei, 345 U.S. 206, 210 (1953)). The Court had thus "repeatedly emphasized that 'over no conceivable subject is the legislative power of Congress more complete than it is over the admission of aliens." "Id. at 792 (quoting Oceanic Steam Navigation, 214 U.S. at 339). Fiallo and Diaz rely directly and uncritically on 'he original plenary power cases, including the Chinese Exclusion Case and Fong Yue Ting, as well as a series of cases decided in the early 1950s affording extraordinary deference to Congress and the Executive in their exclusion, detention, and deportation of aliens on ideological and "security" grounds. See, e.g., Galvan v. Press, 347 U.S. 522, 530-32 (1954) (upholding the deportation of a long-term resident alien under the Internal Security Act of 1950 on the ground of membership in the Communist Party between 1944 and 1946, even in the absence of any evidence that the alien was aware of the Party's advocacy of the violent overthrow of the government); Mezei, 345 U.S. at 210 (upholding the exclusion and 
course, demonstrating that the origins of a legal doctrine lie in an anachronistic worldview does not necessarily render the doctrine itself obsolete or illegitimate. Denaturalizing the inherited premise of immigration exceptionalism does, however, better equip us to undertake a critical, clear-eyed reassessment of the plenary power doctrine.

Second, the history of the period before the adoption of the plenary power doctrine reminds us that many of the issues that animate most immigration regulation today, as in the nineteenth century-labor, economic dependency, and crime-do not bear an obvious connection with foreign affairs or national security. In the six decades preceding the Chinese Exclusion Case, the states, and later the federal government, regulated pauperism and crime among immigrants, sought to mitigate the effect of immigrant labor on domestic wages, and managed the United States' commercial relations with foreign nations. This history begs the question of whether the issues that continue to underlie the vast majority of immigration lawmaking and enforcement today do not in fact have more in common with federal criminal law, the administration of public benefits, and the regulation of labor markets-that is, matters that are today regulated under the commerce power and subject to normal constitutional constraints-than with the conduct of foreign affairs or national security.

Although it is not the principal aim of this Article to set forth a specific proposal or strategy for doctrinal reform, I would like to sketch briefly a few practical implications of abandoning the categorical presumption that all laws and enforcement actions touching on immigration necessarily bear on foreign affairs or national security. Indeed, notwithstanding the extraordinary durability of immigration exceptionalism, there is evidence that the federal courts' commitment to the plenary power doctrine has softened

twenty-one-month detention of a returning long-term resident alien without a hearing on the basis of confidential "security" reasons, on the ground that the power to exclude and expel aliens is "a fundamental sovereign attribute exercised by the Government's political departments largely immune from judicial control"); Harisiades v. Shaughnessy, 342 U.S. 580, 58790 (1952) (upholding the deportation of a long-term legal resident alien because of past membership in the Communist Party, even though he had terminated his membership years before Congress made it cause for deportation). 


\section{somewhat in recent decades. ${ }^{245}$ Such a conceptual shift would effectively disaggregate immigration law for the purpose of constitutional review, thus}

\footnotetext{
${ }^{245}$ This "softening" appears in two broad judicial trends. First, courts frequently smuggle substantive constitutional norms into their immigration decisions in the guise of ostensibly nonsubstantive review, such as procedural due process or statutory construction. As Hiroshi Motomura has demonstrated, "procedural due process claims have come to serve as surrogates ... for the substantive constitutional rights that the plenary power doctrine appears to foreclose." Motomura, supra note 15, at 1656. A judge who has constitutional reservations about the government's conduct can construe the constitutional challenge as "procedural," and then invalidate it on due process grounds, $i d$. at 1628 , thus "channel[ing] its substantive concerns through a mode of judicial review that smacked less of outright judicial supremacy ...." Id. at 1647. The Court's recent decision in Zadvydas v. Davis suggests that statutory construction, too, can function as a kind of surrogate for substantive constitutional review. In that case, the Court read into a statute that appeared to authorize the indefinite detention of aliens pending removal an implicit time limitation of six months, in order to avoid a "serious constitutional problem." 533 U.S. 678, 690 (2001).
}

Second, in at least two recent decisions, the Court has signaled a certain apprehension toward the plenary power doctrine in general, and the national security rationale in particular. In Zadvydas, the offhand manner in which the Court shook off the historical weight of the plenary power doctrine, casually observing that the immigration power was "subject to important constitutional limitations," suggests a majority resistant to the peremptory quality of the judicial branch's traditionally broad deference in immigration matters. The Zadvydas Court likewise rejected the government's invocation of foreign affairs and national security as a warrant for broad deference. The Court specifically, if briefly, weighed and rejected the merits of the government's asserted "foreign policy consideration"- -namely, the risk of interfering with "sensitive' repatriation negotiations." $I d$. at 696 . "[N]either the Government nor the dissents explain how a habeas court's efforts to determine the likelihood of repatriation could make a significant difference in this respect," the Court observed. Id. Even in the context of the so-called "war on terrorism," the Court has declined to defer categorically to the government's invocation of national security to shield from judicial review its detention of noncitizens. In Boumediene v. Bush, for example, the Court extended habeas corpus rights to noncitizen Guantanamo detainees who had been designated "enemy combatants," notwithstanding the government's asserted interest in "apprehend[ing] and detain[ing] those who pose a real danger to our security." 128 S. Ct. 2229, 2277 (2008). "In considering both the procedural and substantive standards used to impose detention to prevent acts of terrorism," the Court granted that "proper deference must be accorded to the political branches." Id. at 2276. However, Justice Kennedy reasoned, "[s]ecurity subsists, too, in fidelity to freedom's first principles." Id. at 2277. "Chief among these," he continued, "are freedom from arbitrary and unlawful restraint and the personal liberty that is secured by adherence to the separation of powers. It is from these principles that the judicial authority to consider petitions for habeas corpus relief derive." Id. To be sure, Boumediene is not an immigration case, and I do not claim that a decision declining to defer to the government's asserted national security interest in the context of the detention of enemy combatants necessarily translates directly to Congress's plenary power over immigration. Its implications, if any, for constitutional immigration law are far from clear. It does demonstrate, however, that in certain contexts-even national security - the Court is prepared to rebuff the rationale for judicial deference that undergirds immigration exceptionalism.

I do not suggest, as some scholars have, that Zadvydas heralds the abandonment of the plenary power doctrine. See, e.g., Peter J. Spiro, Explaining the End of Plenary Power, 16 Geo. ImMigr. L.J. 339 (2002). Indeed, even as Zadvydas gestured toward constitutional limitations on the immigration power, and imposed such a limitation through what can be charitably described as a strained reading of the challenged statute, it also reaffirmed key precedential pillars of the plenary power doctrine-for example, Mezei, 345 U.S. at 212 (stating that "[w]hatever the procedure authorized by Congress is, is due process as far as an alien denied entry is concerned") - - and provides little indication that the Court expects to engage in meaningful review of clearly drawn congressional detention policy. Even after straining to avoid the "serious constitutional problem" that would be presented by a statutory provision authoriz- 
enabling both Congress and the Court to approach each aspect of immigration regulation on its own terms, in a manner appropriate to its specific content and context. "Immigration law" would be understood constitutionally not as a discreet body of law circumscribed by the noncitizenship of its subjects, but rather as a variegated constellation of regulations that often touch the constitutional rights of individuals and that occasionally implicate issues that may warrant heightened deference to Congress and the Executive. Recasting the federal immigration power as but one instance of Congress's "plenary" power to regulate commerce, for example, would carry with it a presumption that regulations of immigrants and immigration are subject to the same substantive, judicially enforceable constitutional norms as most other federal laws, including criminal laws, economic regulation, the administration of public benefits, and antidiscrimination laws.

Under such an approach, the Court would subject the government's detention of Hyung Joon Kim to the same "heightened, substantive due process scrutiny" 246 that applies when the state physically confines a citizen. In Kim's case, this would mean closely scrutinizing, and likely rejecting, Congress's categorical judgment to subject an undifferentiated class of deportable criminal aliens to mandatory detention pending removal, and requiring instead an individualized assessment of both Kim's liberty interest and the government's asserted purpose. As Justice Souter wrote in dissent, "[d]ue process calls for an individual determination before someone is locked away."247 Abandoning the plenary power doctrine would subject a host of other areas of immigration law to meaningful and judicially enforceable constitutional constraints, including procedural rights at the border; ${ }^{248}$ the right to challenge selection for removal on the basis of constitutionally protected speech or associations; ${ }^{249}$ and discrimination against aliens in the receipt of public benefits. ${ }^{250}$

ing indefinite detention, the Court conceded that it would have had to uphold such a provision if the statute had been explicit: "Despite this constitutional problem, if "Congress had made its intent' in the statute 'clear, we must give effect to that intent." 'Zadvydas, 533 U.S. at 696 (quoting Miller v. French, 530 U.S. 327, 336 (2000)); see generally Aleinikoff, supra note 13.

${ }^{246}$ Hyung Joon Kim, 538 U.S. at 549 (Souter, J., dissenting) (quoting Reno v. Flores, 507 U.S. 292,316 (1993)).

${ }^{247} \mathrm{Id}$. at 551 (Souter, J., dissenting).

248 See, e.g., Knauff v. Shaughnessy, 338 U.S. 537, 538 (1950) ("Whatever procedure authorized by Congress is, it is due process as far as an alien denied entry is concerned.").

${ }^{249}$ See, e.g., Reno v. Arab-American Anti-Discrimination Comm'n, 525 U.S. 471, 481-82 (1999) (upholding a federal provision stripping the federal courts of jurisdiction to hear resident aliens' claims that they were targeted for deportation because of their affiliation with a politically unpopular group); Galvan v. Press, 347 U.S. 522, 530-32 (1954) (upholding deportation for past Communist Party membership); Harisiades v. Shaughnessy, 342 U.S. 580, 58790 (1952) (same).

${ }^{250}$ Federal statutes that discriminate on the basis of alienage in the receipt of public benefits receive considerable judicial deference. The leading case is Mathews $v$. Diaz, in which the Supreme Court held that a five-year residency requirement for participation in a federal medical insurance program did not deprive aliens of liberty or property without due process of law. 426 U.S. 67,69 (1976). The Court explained, "[t]he reasons that preclude judicial review of 
In 1954, the Supreme Court upheld the deportation of Juan Galvan, a thirty-year resident of the United States who had an American wife and four native-born children, because he had briefly been a member of the Communist Party at a time when such membership was neither illegal nor grounds for deportation. Writing for the Court, Justice Frankfurter acknowledged that because Galvan was a "person," and thus entitled to "the same protection for his life, liberty and property as . . . a citizen," the decision "strikes one with a sense of harsh incongruity."251 "Much could be said for the view," he observed, "were we writing on a clean slate, that the Due Process Clause qualifies the scope of [Congress's] political discretion . . . in regulating the entry and deportation of aliens." ${ }^{252}$ Frankfurter continued:

But the slate is not clean. As to the extent of the power of Congress under review, there is not merely a page of history, [citation omitted] but a whole volume. Policies pertaining to the entry of aliens and their right to remain here are peculiarly concerned with the political conduct of government .... [T] [ hat the formulation of these polices is entrusted exclusively to Congress has become about as firmly imbedded in the legislative and judicial tissues of our body politic as any aspect of our government. ${ }^{253}$

Frankfurter's misgivings about the result notwithstanding, the justices in the majority were "not prepared to deem ourselves wiser or more sensitive to human rights than our predecessors," ${ }^{254}$ and thus grudgingly upheld Galvan's deportation.

Frankfurter was certainly correct that the slate is not clean. As the history recounted in this Article suggests, the "slate" of the American immigration power is in fact a palimpsest of anachronisms: alien invasions, existential threats to the republic, and simple racism. If the plenary power doctrine is going to survive into the future-if Congress and the Court are going to continue to withhold from immigrants important constitutional rights to which they, as persons, would otherwise be entitled-it should at the very least be on grounds that today's policymakers and judges recognize as legitimate and intellectually coherent.

political questions also dictate a narrow standard of review of decisions made by the Congress or the President in the area of immigration and naturalization." Id. at 81-82. Based on the Court's reasoning in Mathews, the lower federal courts have applied rational basis review to the exclusion of permanent resident aliens from various federally funded welfare programs under the Welfare Reform Act of 1996. See, e.g., Shalala v. City of Chicago, 189 F.3d 598 (7th Cir. 1999); Rodriguez ex rel. Rodriguez v. United States, 169 F.3d 1342 (11 th Cir. 1999); see generally AlEinikofF, supra note 13, at 166.

251 Galvan, 347 U.S. at 530.

${ }^{252}$ Id. at 530-31.

${ }^{253} \mathrm{Id}$. at 531 (citation omitted).

${ }^{254} \mathrm{Id}$. 